\title{
Wet deposition of atmospheric inorganic nitrogen at five remote sites in the Tibetan Plateau
}

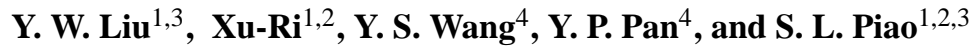 \\ ${ }^{1}$ Key Laboratory of Alpine Ecology and Biodiversity, Institute of Tibetan Plateau Research, Chinese Academy of Sciences, \\ Beijing 100101, China \\ ${ }^{2}$ CAS Center for Excellence in Tibetan Plateau Earth Sciences, Beijing 100101, China \\ ${ }^{3}$ Sino-French Institute for Earth System Science, College of Urban and Environmental Sciences, Peking University, Beijing \\ 100871, China \\ ${ }^{4}$ State Key Laboratory of Atmospheric Boundary Layer Physics and Atmospheric Chemistry (LAPC), Institute of \\ Atmospheric Physics, Chinese Academy of Sciences, Beijing 100029, China
}

Correspondence to: Xu-Ri (xu-ri@itpcas.ac.cn)

Received: 10 April 2015 - Published in Atmos. Chem. Phys. Discuss.: 29 June 2015

Revised: 22 September 2015 - Accepted: 29 September 2015 - Published: 21 October 2015

\begin{abstract}
Since the mid-20th century, nitrogen (N) deposition has shown an increasing trend in the Tibetan Plateau (TP), where alpine ecosystems are sensitive to elevated $\mathrm{N}$ deposition. However, the quantitative characterization of $\mathrm{N}$ deposition in the TP remains unclear, due in most part to the lack of in situ measurement. Using the Tibetan Observation and Research Platform network, we conducted shortterm in situ measurements of major ions $\left(\mathrm{NO}_{3}^{-}, \mathrm{Cl}^{-}, \mathrm{SO}_{4}^{2-}\right.$, $\mathrm{NH}_{4}^{+}, \mathrm{Na}^{+}, \mathrm{K}^{+}, \mathrm{Ca}^{2+}$, and $\mathrm{Mg}^{2+}$ ) wet deposition at five remote sites in the TP during 2011-2013. At Southeast Tibet Station, Nam Co Station, Qomolangma Station, Ngari Station, and Muztagh Ata Station, the $\mathrm{NH}_{4}^{+}-\mathrm{N}$ wet deposition was $0.63,0.68,0.92,0.36$, and $1.25 \mathrm{~kg} \mathrm{Nha}^{-1} \mathrm{yr}^{-1}$, respectively; the $\mathrm{NO}_{3}^{-}-\mathrm{N}$ wet deposition was $0.28,0.24$, $0.03,0.08$, and $0.30 \mathrm{~kg} \mathrm{Nha}^{-1} \mathrm{yr}^{-1}$, respectively; and the inorganic $\mathrm{N}$ wet deposition was $0.91,0.92,0.94,0.44$, and $1.55 \mathrm{~kg} \mathrm{Nha}^{-1} \mathrm{yr}^{-1}$, respectively. The inorganic $\mathrm{N}$ wet deposition mainly occurred in the form of $\mathrm{NH}_{4}^{+}-\mathrm{N}$ during summer at all sites. Results of enrichment factor analysis and principal component analysis demonstrated that both $\mathrm{NH}_{4}^{+}-$ $\mathrm{N}$ and $\mathrm{NO}_{3}^{-}-\mathrm{N}$ wet deposition in the TP were mainly influenced by anthropogenic activities. Backward trajectory analysis showed that the inorganic $\mathrm{N}$ deposition at Muztagh Ata Station was mainly transported from central Asia and the Middle East through westerlies. At Southeast Tibet Station, Nam Co Station, Qomolangma Station, and Ngari Station, the inorganic $\mathrm{N}$ deposition was mainly contributed by anthro-
\end{abstract}

pogenic sources in south Asia, and was mainly transported by the Indian monsoon. Combining site-scale in situ measurements of inorganic $\mathrm{N}$ wet deposition in this and previous studies, the average wet deposition of atmospheric $\mathrm{NH}_{4}^{+}-$ $\mathrm{N}, \mathrm{NO}_{3}^{-}-\mathrm{N}$, and inorganic $\mathrm{N}$ in the TP was estimated to be $1.06,0.51$, and $1.58 \mathrm{kgNha}^{-1} \mathrm{yr}^{-1}$, respectively. The average $\mathrm{NH}_{4}^{+}-\mathrm{N}: \mathrm{NO}_{3}^{-}-\mathrm{N}$ ratio in precipitation in the TP was approximately $2: 1$. Results from the present study suggest that earlier estimations based on chemical transport model simulations and/or limited field measurements likely overestimated substantially the regional inorganic $\mathrm{N}$ wet deposition in the TP. To clarify the total $\mathrm{N}$ deposition in the TP more clearly, it is essential to conduct long-term monitoring of both wet and dry deposition of atmospheric $\mathrm{N}$ in various climate zones in the TP in the future.

\section{Introduction}

The global nitrogen $(\mathrm{N})$ cycle has been disturbed by elevated reactive $\mathrm{N}$ emissions from anthropogenic activities since the mid-19th century (Canfield et al., 2010; Galloway et al., 2008; Gruber and Galloway, 2008). Accumulated reactive $\mathrm{N}$ in the environment has led to a series of effects on climate change and ecosystems, e.g., air pollution, stratospheric ozone depletion, the potential alteration of global temperature, drinking water contamination, 
freshwater eutrophication, biodiversity loss, grassland seed bank depletion, and dead zones in coastal ecosystems (Basto et al., 2015; Erisman et al., 2011; Erisman et al., 2013; Lan et al., 2015; Pinder et al., 2012; Shi et al., 2015; Zaehle et al., 2010). To examine the actual amount of $\mathrm{N}$ inputted into ecosystems, several monitoring networks have been established at national or continent scales, e.g., the National Atmospheric Deposition Program National Trends Network (NADP/NTN, United States) (Lehmann et al., 2005), the Canadian Air and Precipitation Monitoring Network (CAPMoN, Canada) (Zbieranowski and Aherne, 2011), the European Monitoring and Evaluation Programme (EMEP, Europe) (Fagerli and Aas, 2008), the Austrian Precipitation Sampling Network (Austria) (Puxbaum et al., 2002), and the Japanese Acid Deposition Survey (JADS, Japan) (Morino et al., 2011).

Besides Europe and North America, east Asia has become another high $\mathrm{N}$ deposition region, due to rapid economic growth in recent decades (Dentener et al., 2006). Across China, inorganic $\mathrm{N}$ wet deposition has increased since the mid-20th century, albeit with inconsistent estimations of the change: $8 \mathrm{kgNha}^{-1} \mathrm{yr}^{-1}$ (from $13.2 \mathrm{~kg} \mathrm{Nha}^{-1} \mathrm{yr}^{-1}$ in the $1980 \mathrm{~s}$ to $21.1 \mathrm{~kg} \mathrm{Nha}^{-1} \mathrm{yr}^{-1}$ in the 2000s) (X. J. Liu et al., 2013), $2.8 \mathrm{~kg} \mathrm{Nha}^{-1} \mathrm{yr}^{-1}$ (from $11.11 \mathrm{~kg} \mathrm{Nha}^{-1} \mathrm{yr}^{-1}$ in the 1980 s to $13.87 \mathrm{~kg} \mathrm{Nha}^{-1} \mathrm{yr}^{-1}$ in the $2000 \mathrm{~s}$ ) (Jia et al., 2014), and $7.4 \mathrm{~kg} \mathrm{Nha}^{-1} \mathrm{yr}^{-1}$ (from $12.64 \mathrm{~kg} \mathrm{Nha}^{-1} \mathrm{yr}^{-1}$ in the $1960 \mathrm{~s}$ to $20.07 \mathrm{~kg} \mathrm{Nha}^{-1} \mathrm{yr}^{-1}$ in the $2000 \mathrm{~s}$ ) (Lu and Tian, 2014). Enhanced N deposition has changed the structure and function of terrestrial, aquatic and coastal ecosystems in China (Liu et al., 2011). To accurately estimate the $\mathrm{N}$ deposition in China, several monitoring networks have been established at the regional scale, e.g., in northern China (Pan et al., 2012), in forest ecosystems along the North-South Transect of Eastern China (NSTEC; based on the ChinaFLUX network) (Sheng et al., 2013), and in subtropical forest ecosystems in southern China (Chen and Mulder, 2007). However, there are few observation sites distributed in western China, particularly in the Tibetan Plateau (TP), resulting in uncertainty regarding the $\mathrm{N}$ deposition for China as a whole (Jia et al., 2014; X. J. Liu et al., 2013; Lu and Tian, 2014).

The TP covers an area of about 2.57 million $\mathrm{km}^{2}$, occupying approximately one-fourth of the land area of China (Zhang et al., 2002). Over the TP, alpine ecosystems are widely distributed and are sensitive to elevated $\mathrm{N}$ deposition. Multi-level $\mathrm{N}$ fertilization experiments have shown that alpine grassland ecosystems are $\mathrm{N}$ limited and have potential capacity to absorb increased $\mathrm{N}$ deposition (Y. W. Liu et al., 2013; Xu et al., 2014). However, long-term N addition can decrease the species richness of both vegetation and soil seed banks in alpine meadow ecosystems in the TP (Ma et al., 2014). Ice core records show that the inorganic $\mathrm{N}$ deposition in the TP has increased during recent decades (Hou et al., 2003; Kang et al., 2002a, b; Thompson et al., 2000; Zhao et al., 2011; Zheng et al., 2010). This trend is also apparent in sediment cores of alpine lakes in the western and southeast-

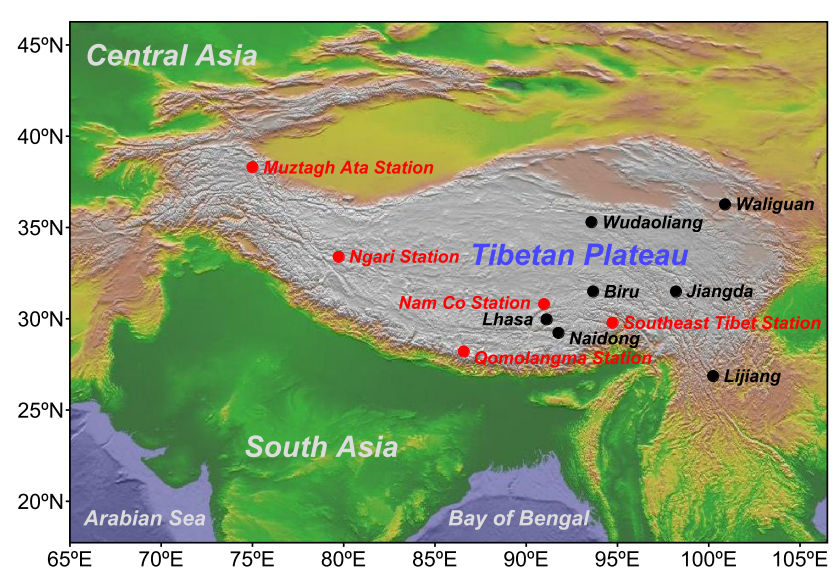

Figure 1. Map of the inorganic $\mathrm{N}$ wet deposition sampling sites in the TP. The red points indicate the five remote sampling sites of this study. The black points indicate the sampling sites from previous records. Southeast Tibet Station is short for Southeast Tibet Observation and Research Station for the Alpine Environment, Chinese Academy of Sciences; Nam Co Station is short for Nam Co Monitoring and Research Station for Multisphere Interactions, Chinese Academy of Sciences; Qomolangma Station is short for Qomolangma Atmospheric and Environmental Observation and Research Station, Chinese Academy of Sciences; Ngari Station is short for Ngari Desert Observation and Research Station; and Muztagh Ata Station is short for Muztagh Ata Westerly Observation and Research Station.

ern TP (Choudhary et al., 2013; Hu et al., 2014). To recognize the characteristics of ion deposition in the TP, a number of observations of precipitation chemistry have been carried out in the eastern TP in recent years (Jia, 2008; Tang et al., 2000; Zhang et al., 2003; N. N. Zhang et al., 2012). Nevertheless, in the central and western TP, observation sites are scarce, indicating that the situation in terms of $\mathrm{N}$ deposition across the entire TP remains unclear.

To quantitatively estimate the inorganic $\mathrm{N}$ wet deposition in the TP, we investigated the precipitation chemistry characteristics at five remote sites, situated mainly in the central and western TP. The sites are part of the Tibetan Observation and Research Platform (TORP) network (Ma et al., 2008). Specifically, our aims were to (1) clarify the characteristics of inorganic $\mathrm{N}$ wet deposition in the central and western TP, and (2) quantitatively assess the inorganic $\mathrm{N}$ wet deposition in the entire TP by combining site-scale in situ measurements in this and previous studies.

\section{Materials and methods}

\subsection{Precipitation sampling and chemical analysis}

Using the TORP network (Ma et al., 2008), precipitation chemistry observations were conducted at five sampling sites: Southeast Tibet Station, Nam Co Station, Qomolangma 
Table 1. Descriptions of the five precipitation sampling sites in the TP.

\begin{tabular}{|c|c|c|c|c|c|c|c|c|}
\hline Station name & Station name expanded & Latitude & Longitude & $\begin{array}{l}\text { Altitude } \\
\text { m a.s.1. }\end{array}$ & $\begin{array}{l}\text { Annual mean } \\
\text { temperature } \\
{ }^{\circ} \mathrm{C}\end{array}$ & $\begin{array}{l}\text { Annual } \\
\text { precipitation } \\
\mathrm{mm} \mathrm{yr}^{-1}\end{array}$ & Vegetation type & References \\
\hline Southeast Tibet Station & $\begin{array}{l}\text { Southeast Tibet Obser- } \\
\text { vation and Research } \\
\text { Station for the Alpine } \\
\text { Environment, Chinese } \\
\text { Academy of Sciences }\end{array}$ & $29^{\circ} 46^{\prime} \mathrm{N}$ & $94^{\circ} 44^{\prime} \mathrm{E}$ & 3326 & 5.6 & $800-1000$ & $\begin{array}{l}\text { Subalpine conif- } \\
\text { erous forest and } \\
\text { temperate de- } \\
\text { ciduous conifer } \\
\text { mixed forest }\end{array}$ & $\begin{array}{ll}\text { Wang } & \text { et } \\
\text { al. }(2010) & \end{array}$ \\
\hline Nam Co Station & $\begin{array}{l}\text { Nam Co Monitoring } \\
\text { and Research Station } \\
\text { for Multisphere Interac- } \\
\text { tions, Chinese Academy } \\
\text { of Sciences }\end{array}$ & $30^{\circ} 47^{\prime} \mathrm{N}$ & $90^{\circ} 58^{\prime} \mathrm{E}$ & 4730 & -0.6 & 414.6 & $\begin{array}{l}\text { Alpine meadow } \\
\text { and } \quad \text { alpine } \\
\text { steppe }\end{array}$ & $\begin{array}{l}\text { Zhang et } \\
\text { al. (2011) }\end{array}$ \\
\hline Qomolangma Station & $\begin{array}{l}\text { Qomolangma Atmo- } \\
\text { spheric and Environ- } \\
\text { mental Observation } \\
\text { and Research Station, } \\
\text { Chinese Academy of } \\
\text { Sciences }\end{array}$ & $28^{\circ} 13^{\prime} \mathrm{N}$ & $86^{\circ} 34^{\prime} \mathrm{E}$ & 4300 & 3.9 & 402.8 & $\begin{array}{l}\text { Alpine meadow } \\
\text { and } \quad \text { alpine } \\
\text { steppe }\end{array}$ & $\begin{array}{l}\text { Gao et } \\
\text { al. (2014) } \\
\text { and M. Li et } \\
\text { al. }(2007)\end{array}$ \\
\hline Ngari Station & $\begin{array}{l}\text { Ngari Desert Observa- } \\
\text { tion and Research Sta- } \\
\text { tion }\end{array}$ & $33^{\circ} 24^{\prime} \mathrm{N}$ & $79^{\circ} 43^{\prime} \mathrm{E}$ & 4264 & - & 124.6 & Desert steppe & This study \\
\hline Muztagh Ata Station & $\begin{array}{l}\text { Muztagh Ata West- } \\
\text { erly Observation and } \\
\text { Research Station }\end{array}$ & $38^{\circ} 17^{\prime} \mathrm{N}$ & $75^{\circ} 1^{\prime} \mathrm{E}$ & 3650 & - & 213.6 & Alpine steppe & This study \\
\hline
\end{tabular}

Station, Ngari Station, and Muztagh Ata Station (Fig. 1), situated from the eastern to western TP and covering various climatic zones and vegetation types. A brief description of the five sites is given in Table 1.

During 2011-2013, we collected precipitation samples at each site, lasting at least 1 year. Precipitation samples were collected following each precipitation event, using an inner removable high-density polyethylene (HDPE) plastic bag in a pre-cleaned HDPE bucket. The HDPE bucket was placed $1.5 \mathrm{~m}$ above the ground. We opened the plastic bag at the beginning of the precipitation event and collected precipitation samples at the end of the precipitation process. Then, the samples were transferred into pre-cleaned HDPE bottles $(50 \mathrm{~mL})$. Snowfall samples were melted at room temperature before being transferred into the HDPE bottles. All samples were kept frozen at the station and during transport until analysis in the laboratory. A total of 259 precipitation samples were collected, among which eight samples were abandoned due to breakage during transportation or the samples volume being less than $10 \mathrm{~mL}$.

We analyzed the chemical composition of all precipitation samplings at the State Key Laboratory of Environmental Aquatic Chemistry, Research Center for Eco-Environmental Sciences, Chinese Academy of Sciences. Analyzed ions included $\mathrm{NO}_{3}^{-}, \mathrm{Cl}^{-}, \mathrm{SO}_{4}^{2-}, \mathrm{NH}_{4}^{+}, \mathrm{Na}^{+}, \mathrm{K}^{+}, \mathrm{Ca}^{2+}$, and $\mathrm{Mg}^{2+}$. All ions were analyzed by the Dionex ICS-2100 Ion Chromatography System. Samples for cation analysis were eluted on a Dionex $4 \mathrm{~mm}$ CS12A separatory column using $20 \mathrm{mM}$ methanesulfonic acid solution for an eluent pumped with a flow rate of $1.0 \mathrm{~mL} \mathrm{~min}^{-1}$. Suppression was provided by a
Dionex CSRS 300 suppressor in recycle mode. For anion analysis, an IonPac AS19-HC column, $25 \mathrm{mM} \mathrm{NaOH}$ eluent, and ASRS 300 suppresser were used. The analytical detection limit was $2 \mathrm{ng} \mathrm{g}^{-1}$ for all ions.

\subsection{Data quality control}

Previously documented methods (Rodhe and Granat, 1984; Safai et al., 2004) were used for quality assurance and quality control purposes. Eight $(3.2 \%)$ samples fell outside the range $(m-3 \delta, m+3 \delta)$ and therefore were excluded. Here, $m$ is the mean value and $\delta$ is the standard deviation. The Pearson correlation between $\Sigma_{\text {anions }}$ and $\Sigma_{\text {cations }}$ was $0.82(P<0.001)$, suggesting credible data quality. The ratio of total anions to total cations was calculated following Eq. (1):

$$
\frac{\sum \text { anions }}{\sum \text { cations }}=\frac{\sum_{k=1}^{n}\left(\mathrm{NO}_{3}^{-}+\mathrm{Cl}^{-}+\mathrm{SO}_{4}^{2-}\right)}{\sum_{k=1}^{n}\left(\mathrm{NH}_{4}^{+}+\mathrm{Na}^{+}+\mathrm{K}^{+}+\mathrm{Ca}^{2+}+\mathrm{Mg}^{2+}\right)},
$$

where $n$ is the number of samples, and the unit of ion concentration is $\mu \mathrm{eqL} \mathrm{L}^{-1}$. The ratio of $\Sigma_{\text {anions }} / \Sigma_{\text {cations }}$ was 0.26 , indicating that at least one major anion was not measured (C. Li et al., 2007). Considering that $\mathrm{pH}$ was alkaline in both precipitation and the surface soil layer (Ding et al., 2004; Y. H. Yang et al., 2012), the unmeasured anion was likely $\mathrm{HCO}_{3}^{-}$(C. Li et al., 2007).

\subsection{Statistical analysis}

For each site, consecutive samples in one year-round sampling period were selected to analyze the annual mean values 
of ions. The sampling time windows of the samples used at the five sites were as follows: Southeast Tibet Station, November 2011 to October 2012; Nam Co Station, August 2011 to July 2012; Qomolangma Station, April 2011 to March 2012; Ngari Station, January 2013 to December 2013; and Muztagh Ata Station, January 2011 to December 2011. A total of 168 precipitation samples were selected, among which the number of samples for Southeast Tibet Station, Nam Co Station, Qomolangma Station, Ngari Station, and Muztagh Ata Station was 53, 27, 30, 39, and 19, respectively.

The annual average ion concentration was calculated as the volume-weighted mean (VWM) following Eq. (2):

$C=\frac{\sum_{i=1}^{n}\left(C_{i} \times P_{i}\right)}{\sum_{i=1}^{n} P_{i}}$,

where $C$ is the annual average ion concentration $\left(\mu \mathrm{eq} \mathrm{L}^{-1}\right)$, $C_{i}$ is the ion concentration of an individual sample $i$ ( $\mu$ eq $\mathrm{L}^{-1}$ ), and $P_{i}$ is the precipitation amount corresponding to the sample $i$ (mm).

Wet deposition of atmospheric $\mathrm{N}$ was calculated following Eq. (3):

$N_{\text {wet }}=0.00014 \times C_{\mathrm{N}} \times P_{\text {annual }}$,

where $N_{\text {wet }}$ is the annual wet deposition of atmospheric inorganic $\mathrm{N}\left(\mathrm{NH}_{4}^{+}-\mathrm{N}\right.$ or $\left.\mathrm{NO}_{3}^{-}-\mathrm{N}, \mathrm{kg} \mathrm{Nha}^{-1} \mathrm{yr}^{-1}\right) ; C_{\mathrm{N}}$ is the annual average equivalent concentration of $\mathrm{N}$ in precipitation $\left(\mathrm{NH}_{4}^{+}-\mathrm{N}\right.$ or $\left.\mathrm{NO}_{3}^{-}-\mathrm{N}, \mu \mathrm{eqL} \mathrm{L}^{-1}\right) ; P_{\text {annual }}$ is annual precipitation $\left(\mathrm{mm} \mathrm{yr}^{-1}\right)$; and 0.00014 is the shift coefficient for the unit of $\mu \mathrm{eqL} \mathrm{L}^{-1} \mathrm{~mm} \mathrm{yr}^{-1}$ to the unit of $\mathrm{kg} \mathrm{Nha}^{-1} \mathrm{yr}^{-1}$. Here, $1 \mu$ eq $\mathrm{NH}_{4}^{+}-\mathrm{N}$ or $\mathrm{NO}_{3}^{-}-\mathrm{N}$ contains $1 \mu \mathrm{mol} \mathrm{N}$, and the weight of $1 \mu \mathrm{mol} \mathrm{N}$ is $14 \times 10^{-9} \mathrm{~kg}$. Thus, $\mu \mathrm{eqL} \mathrm{L}^{-1} \mathrm{mmyr}^{-1}=$ $14 \times 10^{-9} \mathrm{~kg} \mathrm{~N} \times 10^{3} \mathrm{~m}^{-3} \times 10^{-3} \mathrm{~m} \mathrm{yr}^{-1}=14 \times 10^{-9} \mathrm{~kg} \mathrm{~N}$ $\times 10^{4} \mathrm{ha}^{-1} \mathrm{yr}^{-1}=0.00014 \mathrm{~kg} \mathrm{Nha}^{-1} \mathrm{yr}^{-1}$.

\subsection{Source assessment of ion wet deposition}

\subsubsection{Enrichment factor}

Enrichment factor (EF) has been widely used to examine the source contributions of major ion wet deposition in previous studies (Cao et al., 2009; Chabas and Lefevre, 2000; Kulshrestha et al., 1996; Lu et al., 2011; Okay et al., 2002; Shen et al., 2013; Xiao et al., 2013; Zhang et al., 2007). Commonly, $\mathrm{Na}$ is considered as the best reference element for seawater, due to its almost purely marine origin (Keene et al., 1986; Kulshrestha et al., 2003). Another element, Ca, is normally used as a reference element for continental crust, because $\mathrm{Ca}$ is a typical lithophile element and its composition in soil barely changes (Zhang et al., 2007). In this study, $\mathrm{Na}$ and $\mathrm{Ca}$ were used as a reference element for seawater and continental crust, respectively.

In the TP, multiple lines of evidence demonstrate that $\mathrm{Na}^{+}$in precipitation mainly comes from oceans. Balestrini et al. (2014) monitored the chemical and isotopic compositions of precipitation at the Pyramid International Laboratory
(5050 ma.s.1.) on the southern slope of the Himalayas, and data analysis suggested that $\mathrm{Na}^{+}$and $\mathrm{Cl}^{-}$were derived from the long-range transport of marine aerosols. Ice records in the central Himalayas show that $\mathrm{Cl}^{-} / \mathrm{Na}^{+}$was positively related with the monsoon rainfall in northeast India, and there was a teleconnection between the $\mathrm{Na}^{+}$and $\mathrm{Cl}^{-}$concentrations and the North Atlantic Oscillation, indicating that $\mathrm{Na}^{+}$in the ice core mainly came from oceans (Wang et al., 2002). $\mathrm{Na}^{+}$has been used as a marine tracer when analyzing the source contributions of ion wet deposition in the northeastern TP (Li et al., 2015), the southeastern TP (B. Liu et al., 2013) and the southern slope of central Himalayas (Tripathee et al., 2014).

Over the TP, sandy desertification land covers about $3.1 \times$ $10^{5} \mathrm{~km}^{2}$, accounting for $14 \%$ of the whole plateau, of which moderate sandy desertification land occupies $55.44 \%$ (Liu et al., 2005). The TP is regarded as an important dust source region (Fang et al., 2004; Han et al., 2009, 2008). The TP dust sources contribute $69 \%$ of dust at the surface and $40 \%$ of dust in the lower troposphere over the TP (Mao et al., 2013). Moreover, arid regions are widely distributed surrounding the TP, e.g., central Asia, and the deserts in western China. The dust over the TP partly comes from the adjacent dust source regions, e.g., the Taklimakan Desert in western China (Huang et al., 2007; Xia et al., 2008). Atmospheric dust aerosols over the TP are strongly impacted by local sources and enriched with Ca (Zhang et al., 2001). These dust aerosols in the atmosphere can interact with clouds and precipitation (Huang et al., 2014), and deposit on the surface with precipitation. Thus, $\mathrm{Ca}^{2+}$ is commonly used as a proxy of dust in ice core studies in the TP (Kang et al., 2002a, 2010; Kaspari et al., 2007; Wang et al., 2008). As a dust proxy, the $\mathrm{Ca}^{2+}$ record in an ice core from the central TP was significantly related to regional zonal wind (westerlies) trends and reflected the long-term control of regional atmospheric circulation strength over atmospheric dust concentrations (Grigholm et al., 2015). In addition, Ca also has been used as a reference element for continental crust when assessing sources of ion wet deposition in precipitation in the northern TP (Li et al., 2015).

In this study, the EF of an ion in precipitation relative to the ion in sea was estimated using $\mathrm{Na}$ as a reference element following Eq. (4):

$\mathrm{EF}_{\text {sea }}=\frac{\left[X / \mathrm{Na}^{+}\right]_{\text {rain }}}{\left[X / \mathrm{Na}^{+}\right]_{\text {sea }}}$,

where $\mathrm{EF}_{\text {sea }}$ is the $\mathrm{EF}$ of an ion in precipitation relative to the ion in sea; $X$ is an ion in precipitation; $\left[X / \mathrm{Na}^{+}\right]_{\text {rain }}$ is the ratio of precipitation composition ( $\mu \mathrm{eq} X / \mu \mathrm{eq} \mathrm{Na}{ }^{+}$); and $\left[X / \mathrm{Na}^{+}\right]_{\text {sea }}$ is the ratio of sea composition (Keene et al., 1986; Turekian, 1968) ( $\mu$ eq $X / \mu$ eq $\mathrm{Na}^{+}$).

The EF of an element in precipitation relative to the element in soil was estimated using $\mathrm{Ca}$ as a reference element 
following Eq. (5):

$\mathrm{EF}_{\text {soil }}=\frac{\left[X / \mathrm{Ca}^{2+}\right]_{\text {rain }}}{\left[X / \mathrm{Ca}^{2+}\right]_{\text {soil }}}$,

where $\mathrm{EF}_{\text {soil }}$ is the $\mathrm{EF}$ of an element in precipitation relative to the element in soil; $X$ is an ion in precipitation; $\left[X / \mathrm{Ca}^{2+}\right]_{\text {rain }}$ is the ratio of precipitation composition $(\mu \mathrm{g}$ $\left.X / \mu \mathrm{g} \mathrm{Ca}^{2+}\right)$; and $\left[X / \mathrm{Ca}^{2+}\right]_{\text {soil }}$ is the ratio of soil composition (Taylor, 1964) $\left(\mu \mathrm{g} X / \mu \mathrm{g} \mathrm{Ca}{ }^{2+}\right)$.

To estimate fractions of marine, crustal and anthropogenic sources contributed to ions in precipitation, we calculated the sources of ionic components in precipitation using equations from previous studies (Cao et al., 2009; Lu et al., 2011; Zhang et al., 2007) as follows:

$\operatorname{SSF}(\%)=\frac{\left[X / \mathrm{Na}^{+}\right]_{\text {sea }}}{\left[X / \mathrm{Na}^{+}\right]_{\text {rain }}} \times 100$,

$\mathrm{CF}(\%)=\frac{\left[X / \mathrm{Ca}^{2+}\right]_{\text {soil }}}{\left[X / \mathrm{Ca}^{2+}\right]_{\text {rain }}} \times 100$,

$\mathrm{AF}(\%)=100-\mathrm{SSF}-\mathrm{CF}$,

where SSF is sea salt fraction; CF is crust fraction; and AF is anthropogenic fraction. Note that, if SSF is greater than 1 , $\mathrm{SSF}$ is recalculated as the difference between 1 and $\mathrm{CF}$; if $\mathrm{CF}$ is greater than $1, \mathrm{CF}$ is recalculated as the difference between 1 and SSF.

\subsubsection{Principal component analysis}

Principal component analysis has been widely used in precipitation chemical studies to determine the effect of natural and anthropogenic sources on chemical composition of precipitation (Balasubramanian et al., 2001; Cao et al., 2009; Migliavacca et al., 2005; Zhang et al., 2007). In this study, principal component analysis was also used to examine the various sources of major ions in precipitation at the five remote sites in the TP. Varimax-rotated principal component analysis was performed using "principal" function in package "psych" of R 3.2.0 (R Core Team, 2015; http://www.R-project.org, last visited 16 October 2015).

\subsubsection{Backward trajectory analysis}

To identify the long-range transport of water-soluble ions in precipitation, 7-day backward trajectories arriving at the sampling sites for each individual precipitation event were calculated. Backward trajectories were calculated using TrajStat (version 1.4.4R4, http://www.meteothinker. com/products/trajstat_features.html, last visited 16 October 2015), which is a GIS-based software, including a trajectory calculation module of HYSPLIT (Hybrid Single Particle Lagrangian Integrated Trajectory Model; http://www.arl.

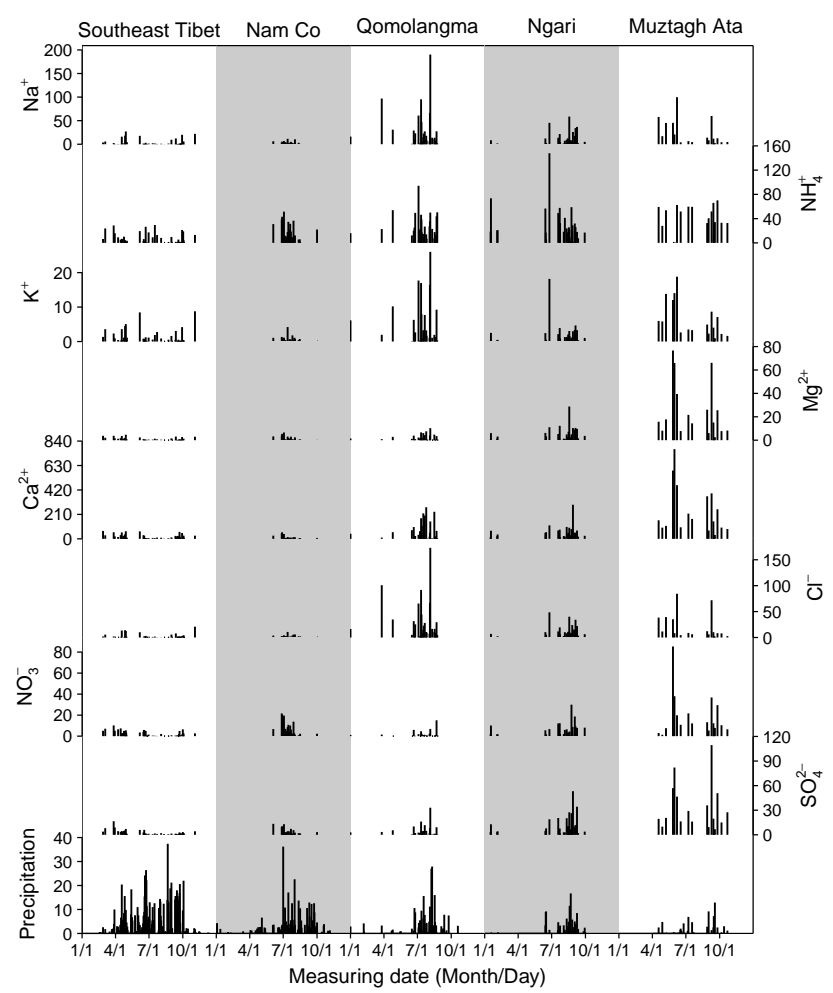

Figure 2. Seasonal dynamics of ion concentrations (unit: $\mu \mathrm{eq} \mathrm{L}^{-1}$ ) and precipitation (unit: $\mathrm{mm}$ ) at five remote sites in the TP. The sampling times of the five sites were as follows: Southeast Tibet Station, November 2011 to October 2012; Nam Co Station, August 2011 to July 2012; Qomolangma Station, April 2011 to March 2012; Ngari Station, January 2013 to December 2013; Muztagh Ata Station, January 2011 to December 2011.

noaa.gov/ready/hysplit4.html, last visited 16 October 2015) (Wang et al., 2009). Meteorological data were input from the Global Data Assimilation System (GDAS) meteorological data archives of the Air Resource Laboratory, National Oceanic and Atmospheric Administration (NOAA) (ftp:// arlftp.arlhq.noaa.gov/pub/archives/gdas1, last visited 16 October 2015). All backward trajectories were calculated at $6 \mathrm{~h}$ intervals (00:00, 06:00, 12:00, 18:00 UTC) at each sampling day, with an arrival height of $500 \mathrm{~m}$ above the ground. Then, cluster analysis was performed using the trajectories during the one year-round sampling period at each site using TrajStat (version 1.4.4R4).

\section{Results}

\subsection{Chemical composition of atmospheric precipitation}

Figure 2 shows the seasonal dynamics of ion concentrations in precipitation at the five remote sites in the TP. Wet deposition of all ions mainly occurs during summer at all sites. Compared to the sites with relatively higher precipitation 

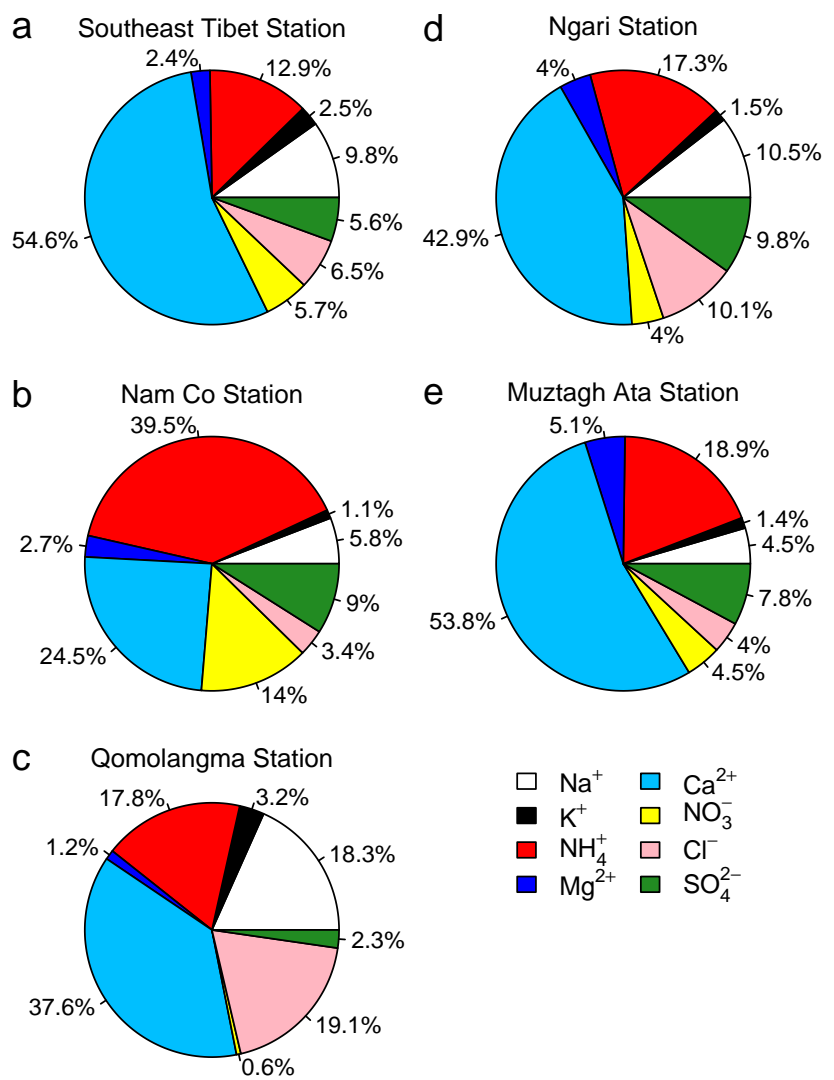

Figure 3. Annual average volume-weighted concentration percentages of measured ions in precipitation (unit: $\mu \mathrm{eq} \mathrm{L}^{-1} / \mu \mathrm{eq} \mathrm{L}^{-1}$ ) at five remote sites in the TP.

amounts, e.g., Southeast Tibet Station and Nam Co Station, the sites with relatively lower precipitation amounts had relatively higher ion concentrations, e.g., Ngari Station and Muztagh Ata Station (Fig. 2, Table 2). $\mathrm{Ca}^{2+}$ had the highest annual VWM concentration in precipitation at most sites (except Nam Co Station), with the highest proportion, accounting for measured ions of $54.6 \%$ at Southeast Tibet Station (Figs. 2 and 3). At Nam Co Station, $\mathrm{NH}_{4}^{+}$in precipitation had the highest proportion accounting for measured ions of $39.5 \%$, higher than those at the other sites (ranging from $12.9 \%$ at Southeast Tibet Station to $18.9 \%$ at Muztagh Ata Station) (Fig. 3). Compared to $\mathrm{NH}_{4}^{+}, \mathrm{NO}_{3}^{-}$had much lower proportion accounting for measured ions in precipitation, ranging from $0.6 \%$ at Qomolangma Station to $14 \%$ at Nam Co Station (Fig. 3). The order of the average annual VWM of ion deposition at the five sites was $\mathrm{Ca}^{2+}>\mathrm{NH}_{4}^{+}>\mathrm{SO}_{4}^{2-}>$ $\mathrm{Cl}^{-}>\mathrm{Na}^{+}>\mathrm{Mg}^{2+}>\mathrm{NO}_{3}^{-}>\mathrm{K}^{+}$(Table 2). All major ion concentrations in precipitation in the TP were much lower than those in northern and southern China (Table 2).

\subsection{Wet deposition of atmospheric inorganic $\mathbf{N}$}

At Southeast Tibet Station, Nam Co Station, Qomolangma Station, Ngari Station, and Muztagh Ata Station, the

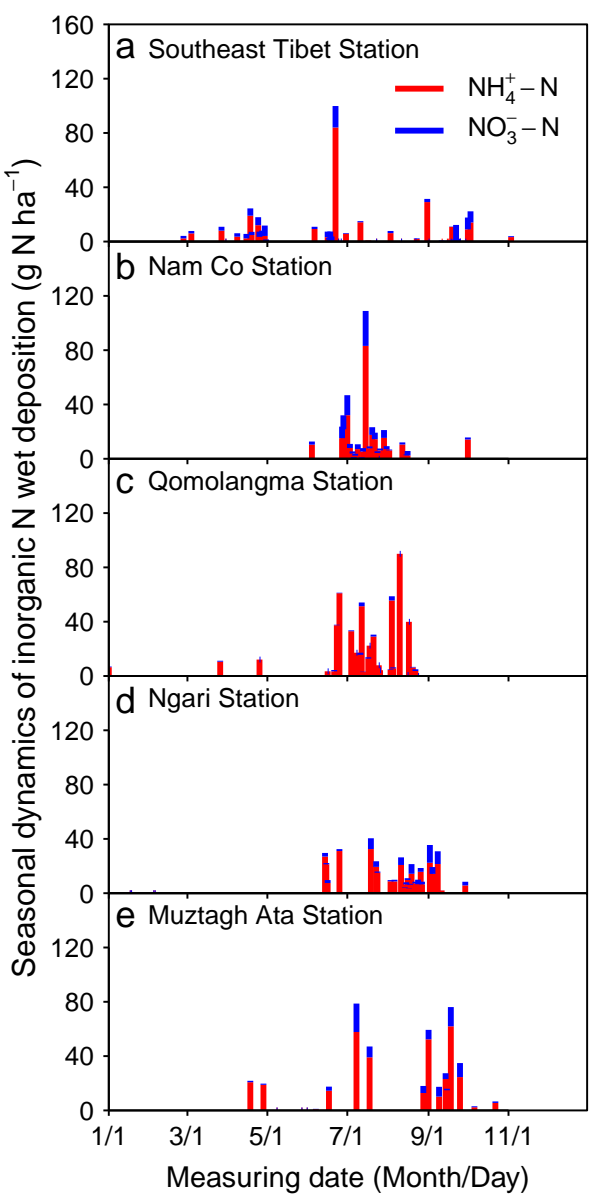

Figure 4. Seasonal dynamics of inorganic $\mathrm{N}$ wet deposition at five remote sites in the TP. The sampling time windows of those sites are the same as in Fig. 2.

$\mathrm{NH}_{4}^{+}-\mathrm{N}$ wet deposition was $0.63,0.68,0.92,0.36$, and $1.25 \mathrm{~kg} \mathrm{Nha}^{-1} \mathrm{yr}^{-1}$, respectively; the $\mathrm{NO}_{3}^{-}-\mathrm{N}$ wet deposition was $0.28,0.24,0.03,0.08$, and $0.30 \mathrm{~kg} \mathrm{Nha}^{-1} \mathrm{yr}^{-1}$, respectively; and the inorganic $\mathrm{N}$ wet deposition was 0.91 , $0.92,0.94,0.44$ and $1.55 \mathrm{~kg} \mathrm{Nha}^{-1} \mathrm{yr}^{-1}$, respectively (Table 3). Besides the above five sites of the TORP network, previous site-scale in situ measurements of inorganic $\mathrm{N}$ wet deposition at other sites in the TP were also collected, e.g., at Waliguan (Tang et al., 2000), Wudaoliang (Yang et al., 1991), Lhasa (Zhang et al., 2003), Naidong (Jia, 2008), Biru (Jia, 2008), Jiangda (Jia, 2008), and Lijiang (N. N. Zhang et al., 2012). Combining the site-scale in situ measurements in our study and those in previous studies, the average wet deposition of atmospheric $\mathrm{NH}_{4}^{+}-\mathrm{N}, \mathrm{NO}_{3}^{-}-\mathrm{N}$, and inorganic $\mathrm{N}$ in the TP was estimated to be $1.06,0.51$, and $1.58 \mathrm{~kg} \mathrm{Nha}^{-1} \mathrm{yr}^{-1}$, respectively, and the estimated $\mathrm{NH}_{4}^{+}-\mathrm{N}: \mathrm{NO}_{3}^{-}-\mathrm{N}$ ratio in precipitation in the TP was approximately $2: 1$. Both $\mathrm{NH}_{4}^{+}$ $\mathrm{N}$ and $\mathrm{NO}_{3}^{-}-\mathrm{N}$ wet deposition in the TP were much lower than those in northern and southern China (Table 3). 


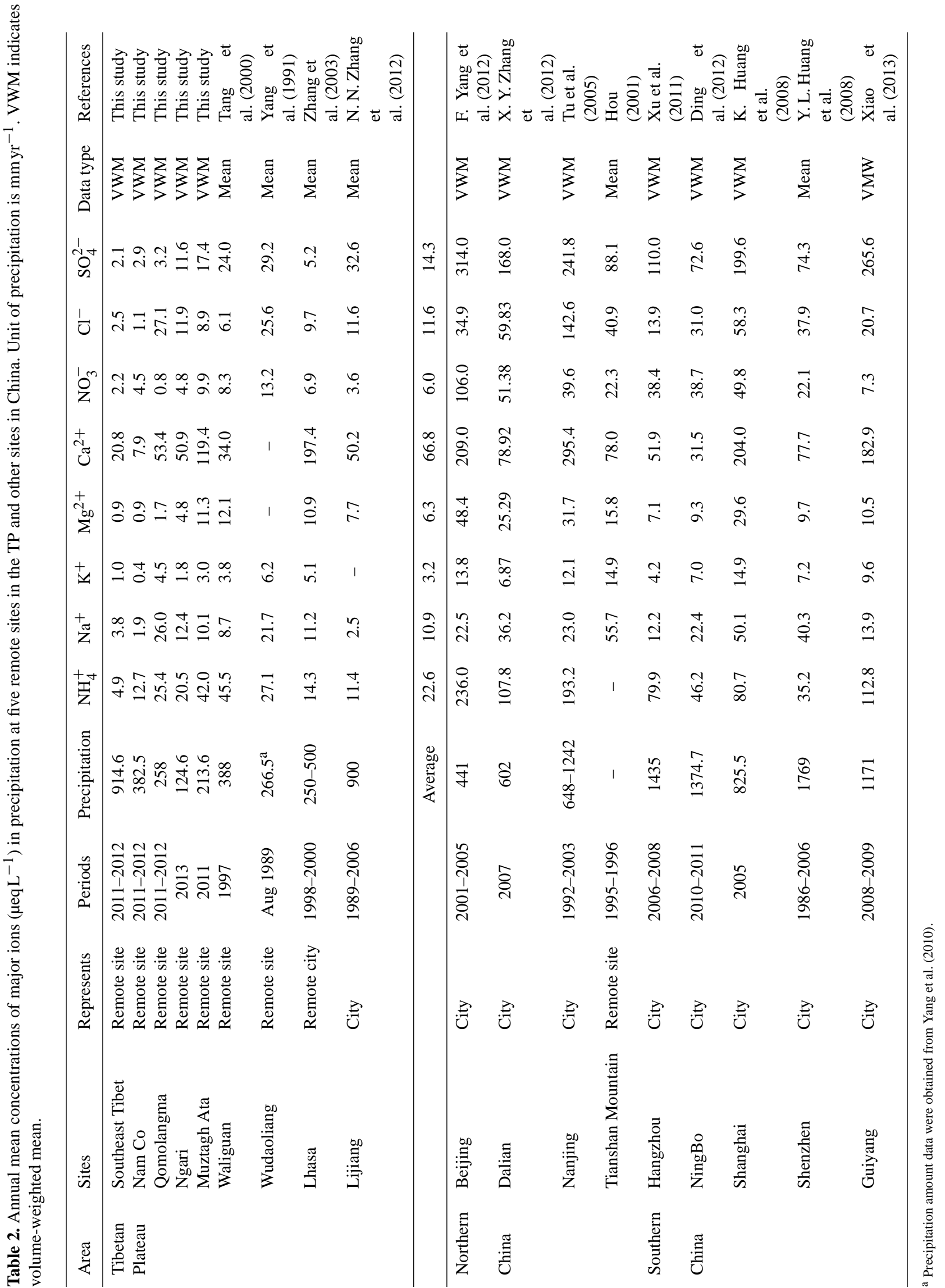


Table 3. Annual inorganic $\mathrm{N}$ wet deposition $\left(\mathrm{kg} \mathrm{N} \mathrm{ha}^{-1} \mathrm{yr}^{-1}\right)$ at five remote sites in the $\mathrm{TP}$, as well as other sites in China. Unit of precipitation is $\mathrm{mm} \mathrm{yr}^{-1}$. Inorganic $\mathrm{N}$ is the sum of $\mathrm{NH}_{4}^{+}-\mathrm{N}$ and $\mathrm{NO}_{3}^{-}-\mathrm{N}$.

\begin{tabular}{|c|c|c|c|c|c|c|c|c|}
\hline Area & Sites & Represents & Periods & Precipitation & $\mathrm{NH}_{4}^{+}-\mathrm{N}$ & $\mathrm{NO}_{3}^{-}-\mathrm{N}$ & Inorganic N & References \\
\hline Tibetan & Southeast Tibet & Remote site & $2011-2012$ & 914.6 & 0.63 & 0.28 & 0.91 & This study \\
\hline \multirow[t]{12}{*}{ Plateau } & Nam Co & Remote site & 2011-2012 & 382.5 & 0.68 & 0.24 & 0.92 & This study \\
\hline & Qomolangma & Remote site & 2011-2012 & 258 & 0.92 & 0.03 & 0.94 & This study \\
\hline & Ngari & Remote site & 2013 & 124.6 & 0.36 & 0.08 & 0.44 & This study \\
\hline & Muztagh Ata & Remote site & 2011 & 213.6 & 1.25 & 0.30 & 1.55 & This study \\
\hline & Waliguan & Remote site & 1997 & 388 & 2.47 & 0.45 & 2.92 & Tang et al. (2000) \\
\hline & Wudaoliang & Remote site & Aug 1989 & $266.5^{\mathrm{a}}$ & 1.01 & 0.49 & 1.50 & Yang et al. (1991) \\
\hline & Lhasa & Remote city & $1998-2000$ & $250-500^{\mathrm{b}}$ & 0.75 & 0.36 & 1.11 & Zhang et al. (2003) \\
\hline & Naidong & Remote city & 2006-2007 & 451 & 0.91 & 0.82 & 1.72 & Jia (2008) \\
\hline & Biru & Remote city & 2006-2007 & 582 & 1.22 & 1.86 & 3.08 & Jia (2008) \\
\hline & Jiangda & Remote city & 2006-2007 & 547 & 1.11 & 0.80 & 1.91 & Jia (2008) \\
\hline & Lijiang & Remote city & 1989-2006 & 900 & 1.43 & 0.46 & 1.89 & $\begin{array}{l}\text { N. N. Zhang et } \\
\text { al. (2012) }\end{array}$ \\
\hline & & & & Average & 1.06 & 0.51 & 1.58 & \\
\hline & Beijing & City & 2001-2005 & 441 & 14.57 & 6.54 & 21.12 & F. Yang et al. (2012) \\
\hline \multirow{12}{*}{ China } & Dalian & City & 2007 & 602 & 9.08 & 4.33 & 13.41 & $\begin{array}{l}\text { X. Y. Zhang et } \\
\text { al. (2012) }\end{array}$ \\
\hline & Nanjing & City & $1992-2003$ & $648-1242^{c}$ & 25.56 & 5.24 & 30.80 & Tu et al. (2005) \\
\hline & Beijing & City & 2008-2010 & 572 & - & - & 27.9 & Pan et al. (2012) \\
\hline & Tianjin & City & $2008-2010$ & 544 & - & - & 18.1 & Pan et al. (2012) \\
\hline & Baoding & Industrial & 2008-2010 & 513 & - & - & 23.1 & Pan et al. (2012) \\
\hline & Tanggu & Industrial & $2008-2010$ & 566 & - & - & 28.2 & Pan et al. (2012) \\
\hline & Tangshan & Industrial & 2008-2010 & 610 & - & - & 21.6 & Pan et al. (2012) \\
\hline & Yangfang & Suburban & 2008-2010 & 404 & - & - & 20.7 & Pan et al. (2012) \\
\hline & Cangzhou & Suburban & $2008-2010$ & 605 & - & - & 22.6 & Pan et al. (2012) \\
\hline & Luancheng & Agricultural & 2008-2010 & 517 & - & - & 22.2 & Pan et al. (2012) \\
\hline & Yucheng & Agricultural & $2008-2010$ & 566 & - & - & 24.8 & Pan et al. (2012) \\
\hline & Xinglong & Rural & 2008-2010 & 512 & - & - & 16.3 & Pan et al. (2012) \\
\hline Southern & Tieshanping & Remote site & 1999-2004 & 1228 & 25.50 & 9.80 & 35.30 & $\begin{array}{l}\text { Chen and Mulder } \\
(2007)\end{array}$ \\
\hline \multirow[t]{9}{*}{ China } & Luchongguan & Remote site & 1999-2004 & 854 & 2.40 & 1.30 & 3.70 & $\begin{array}{l}\text { Chen and Mulder } \\
\text { (2007) }\end{array}$ \\
\hline & Leigongshan & Remote site & 1999-2004 & 1714 & 3.70 & 2.60 & 6.30 & $\begin{array}{l}\text { Chen and Mulder } \\
\text { (2007) }\end{array}$ \\
\hline & Caijiatang & Remote site & 1999-2004 & 1232 & 21.10 & 12.70 & 33.80 & $\begin{array}{l}\text { Chen and Mulder } \\
\text { (2007) }\end{array}$ \\
\hline & Liuxihe & Remote site & 1999-2004 & 1620 & 4.30 & 7.50 & 11.80 & $\begin{array}{l}\text { Chen and Mulder } \\
\text { (2007) }\end{array}$ \\
\hline & Hangzhou & City & 2006-2008 & 1435 & 16.1 & 7.7 & 23.77 & Xu et al. (2011) \\
\hline & Ningbo & City & 2010-2011 & 1374.7 & 8.9 & 7.4 & 16.34 & Ding et al. (2012) \\
\hline & Shanghai & City & 2005 & 825.5 & 9.3 & 5.8 & 15.08 & K. Huang et al. (2008) \\
\hline & Shenzhen & City & 1986-2006 & 1769 & 8.7 & 5.5 & 14.19 & $\begin{array}{l}\text { Y. L. Huang et } \\
\text { al. (2008) }\end{array}$ \\
\hline & Guiyang & City & 2008-2009 & 1171 & 18.5 & 1.2 & 19.69 & Xiao et al. (2013) \\
\hline
\end{tabular}

Notes: Tang et al. (2000), Yang et al. (1991), Zhang et al. (2003), N. N. Zhang et al. (2012), Tu et al. (2005), F. Yang et al. (2012), X. Y. Zhang et al. (2012), Xu et al. (2011), Ding et al. (2012), K. Huang et al. (2008), Y. L. Huang et al. (2008) and Xiao et al. (2013) reported the concentrations of $\mathrm{NH}_{4}^{+}-\mathrm{N}^{-}$and $\mathrm{NO}_{3}^{-}-\mathrm{N}_{\text {in }}$ precipitation but did not calculate $\mathrm{N}$ wet deposition. For these previous studies, we recalculated the annual inorganic $\mathrm{N}$ wet deposition according to the reported concentrations of $\mathrm{NH}_{4}^{+}-\mathrm{N}$ and $\mathrm{NO}_{3}^{-}-\mathrm{N}_{\text {in }}$ precipitation and annual precipitation. ${ }^{a}$ Precipitation amount data were obtained from Yang et al. (2010). ${ }^{\mathrm{b}}$ The mean value of 375 was used to recalculate inorganic $\mathrm{N}$ wet deposition. ${ }^{\mathrm{c}}$ The mean value of 945 was used to recalculate inorganic $\mathrm{N}$ wet deposition. 


\subsection{Seasonal dynamics of inorganic $\mathrm{N}$ wet deposition}

The inorganic $\mathrm{N}$ wet deposition mainly occurred in the form of $\mathrm{NH}_{4}^{+}-\mathrm{N}$ during summer at all sites (Fig. 4). Both concentrations of $\mathrm{NH}_{4}^{+}$and $\mathrm{NO}_{3}^{-}$did not exhibit any clear seasonal pattern (Fig. 2). The seasonal dynamics of inorganic $\mathrm{N}$ wet deposition at most stations appeared in the shape of a single peak type (Fig. 4). The seasonal patterns of inorganic $\mathrm{N}$ wet deposition were similar to the seasonal patterns of precipitation, rather than those of $\mathrm{NH}_{4}^{+}$or $\mathrm{NO}_{3}^{-}$concentration (Fig. 2).

\subsection{Source assessment of wet deposition of inorganic $N$ and other ions}

\subsubsection{Enrichment factors}

Table 4 shows the EFs of precipitation constituents at the five sites relative to seawater and soil. If the EF value of an ion in precipitation is much higher (lower) than 1 , the ion is considered to be enriched (diluted) relative to the reference source. Among the five sites, $\mathrm{Cl}^{-}$had a relatively lower $\mathrm{EF}_{\text {sea }}$ value, ranging from 0.50 (Nam Co Station) to 0.90 (Qomolangma Station), but a relatively higher $\mathrm{EF}_{\text {soil }}$ value, ranging from 42.4 (Muztagh Ata Station) to 286 (Qomolangma Station). Different from $\mathrm{Cl}^{-}, \mathrm{NH}_{4}^{+}$in precipitation was enriched relative to both marine origin and soil reference source at all sites, because its $\mathrm{EF}_{\text {sea }}$ values ranged from 11629 to 80684 , and its $\mathrm{EF}_{\text {soil }}$ ranged from 350 to 2378 . Similar to $\mathrm{NH}_{4}^{+}, \mathrm{NO}_{3}^{-}$ also had a relatively high value of both $\mathrm{EF}_{\text {sea }}$ and $\mathrm{EF}_{\text {soil }}$ at all five sites.

Table 5 shows the source contributions for major ions in precipitation of the five remote sites in this study. Almost all $\mathrm{Cl}^{-}$and $\mathrm{Na}^{+}$in precipitation in the TP appeared to be of marine origin, with SSF value above $95 \%$ at the five sites. Nearly all $\mathrm{Ca}^{2+}$ in precipitation came from crust at the five sites, with the $\mathrm{CF}$ value being above $90 \%$. Across the five sites, anthropogenic sources contributed at least $99 \%$ of $\mathrm{NH}_{4}^{+}$in precipitation. $\mathrm{NO}_{3}^{-}$in precipitation was also mainly influenced by anthropogenic activities, with AF values ranging from 95.3 to $99.9 \%$.

\subsubsection{Principal component analysis}

Table 6 shows the first, second and third component of principal component analysis, which accounted for at least $85 \%$ of the total variance across the five sites. $\mathrm{Na}^{+}$and $\mathrm{Cl}^{-}$were mainly explained by the same component at all sites. Principal component analysis shows that the variances of $\mathrm{Ca}^{2+}$ and $\mathrm{Na}^{+}$were represented by different components at four of five sites (except Southeast Tibet Station) (Table 6). The common variance of $\mathrm{Ca}^{2+}, \mathrm{Mg}^{2+}$ and $\mathrm{SO}_{4}^{2-}$ as the first component represents the largest proportion of the total species variation at the three sites (Nam Co Station, Ngari Station, and Muztagh Ata Station) in the central and western TP (Table 6). At Qomolangma Station, $\mathrm{Na}^{+}, \mathrm{Cl}^{-}, \mathrm{K}^{+}, \mathrm{SO}_{4}^{2-}$ and $\mathrm{NH}_{4}^{+}$as the 
Table 5. Source contributions (\%) for major ions in precipitation of five remote sites in the TP. SSF indicates sea salt fraction; CF indicates crust fraction; AF indicates anthropogenic fraction. Boldfaced values indicate the major contribution for each ion at each site.

\begin{tabular}{|c|c|c|c|c|c|c|c|c|c|c|c|c|c|c|c|}
\hline & \multicolumn{3}{|c|}{ Southeast Tibet Station } & \multicolumn{3}{|c|}{ Nam Co Station } & \multicolumn{3}{|c|}{ Qomolangma Station } & \multicolumn{3}{|c|}{ Ngari Station } & \multicolumn{3}{|c|}{ Muztagh Ata Station } \\
\hline & SSF & $\mathrm{CF}$ & $\mathrm{AF}$ & SSF & $\mathrm{CF}$ & $\mathrm{AF}$ & SSF & $\mathrm{CF}$ & $\mathrm{AF}$ & SSF & $\mathrm{CF}$ & $\mathrm{AF}$ & SSF & $\mathrm{CF}$ & $\mathrm{AF}$ \\
\hline $\mathrm{NH}_{4}^{+}$ & 0.0 & 0.3 & 99.7 & 0.0 & 0.0 & 100 & 0.0 & 0.1 & 99.8 & 0.0 & 0.2 & 99.8 & 0.0 & 0.2 & 99.8 \\
\hline $\mathrm{NO}_{3}^{-}$ & 0.0 & 0.6 & 99.3 & 0.0 & 0.1 & 99.9 & 0.1 & 4.6 & 95.3 & 0.0 & 0.7 & 99.3 & 0.0 & 0.8 & 99.2 \\
\hline $\mathrm{SO}_{4}^{2-}$ & 21.3 & 7.7 & 71.0 & 7.9 & 2.1 & 90.0 & 87.1 & 12.9 & & 12.9 & 3.4 & 83.7 & 7.0 & 5.4 & 87.6 \\
\hline $\mathrm{Ca}^{2+}$ & 0.8 & 99.2 & & 1.0 & 99.0 & & 2.1 & 97.9 & & 1.1 & 98.9 & & 0.4 & 99.6 & \\
\hline $\mathrm{K}^{+}$ & 8.7 & 91.3 & & 11.8 & 88.2 & & 12.8 & 87.2 & & 15.5 & 84.5 & & 7.4 & 92.6 & \\
\hline $\mathrm{Mg}^{2+}$ & 92.9 & 7.1 & & 49.0 & 51.0 & & 0 & 100 & & 59.2 & 40.8 & & 20.2 & 79.8 & \\
\hline $\mathrm{Cl}^{-}$ & 98.5 & 1.5 & & 98.7 & 1.3 & & 99.7 & 0.3 & & 99.2 & 0.8 & & 97.6 & 2.4 & \\
\hline $\mathrm{Na}^{+}$ & 100 & & & 100 & & & 100 & & & 100 & & & 100 & & \\
\hline
\end{tabular}

first component represents the largest proportion of the total species variation (Table 6). Except for Qomolangma Station, at the other four sites, the variances of $\mathrm{NH}_{4}^{+}$were mainly represented by the third component (Table 6). At Southeast Tibet Station, both $\mathrm{Ca}^{2+}$ and $\mathrm{Na}^{+}$variances were mostly represented by the first component, but $\mathrm{NO}_{3}^{-}$variances were mainly represented by the second component (Table 6). At Nam Co Station, Qomolangma Station, and Ngari Station, $\mathrm{NO}_{3}^{-}$variances were mainly represented by the third component, which were different from that of both $\mathrm{Ca}^{2+}$ and $\mathrm{Na}^{+}$ (Table 6). However, $\mathrm{NO}_{3}^{-}$variances were mainly represented by the first component at Muztagh Ata Station (Table 6).

\subsubsection{Backward trajectory analysis}

Figure 5 shows the 7-day backward trajectories of air mass arriving at the five remote sites at the sampling days. The transport pathways of air masses were various with the different sites (Fig. 5). The cluster trajectory results showed that at Muztagh Ata Station nearly all air masses on sampling days were transported from central Asia and the Middle East (Fig. 5a). Different from Muztagh Ata Station, almost all air masses at Nam Co Station were transported from south Asia (Fig. 5d). For Ngari Station, Qomolangma Station, and Southeast Tibet Station, the air masses on sampling days were mainly transported from south Asia, with the proportion of 90, 79.8, and 90.6\%, respectively (Fig. 5b, c, and e). Besides south Asia, central Asia, Qaidam Basin, and the Middle East were the second source of air masses on sampling days for Ngari Station, Qomolangma Station, and Southeast Tibet Station, respectively (Fig. 5b, c, and e).

\section{Discussion}

\subsection{Wet deposition of atmospheric inorganic $N$ in the TP}

According to our previous field observations, wet deposition of atmospheric inorganic $\mathrm{N}$ in the western TP was lower than that in the eastern TP. For example, the rates of inorganic $\mathrm{N}$ wet deposition at Ngari Station and Muztagh Ata Station were 0.44 and $1.55 \mathrm{~kg} \mathrm{Nha}^{-1} \mathrm{yr}^{-1}$, respectively. These inorganic $\mathrm{N}$ wet deposition in the western TP were much lower than those at the sites in the eastern TP, e.g., Jiangda (1.91 kg $\mathrm{N} \mathrm{ha}{ }^{-1} \mathrm{yr}^{-1}$ ), Lijiang $\left(1.89 \mathrm{~kg} \mathrm{~N} \mathrm{ha}^{-1} \mathrm{yr}^{-1}\right)$ and Waliguan (2.92 $\mathrm{kg} \mathrm{N} \mathrm{ha}^{-1} \mathrm{yr}^{-1}$ ) (Table 3). However, the concentrations of inorganic $\mathrm{N}$ in precipitation at the sites in the western TP were comparable to those at the sites in the eastern TP. For instance, the annual average concentrations of $\mathrm{NH}_{4}^{+}$in precipitation at Ngari Station and Muztagh Ata Station were 20.5 and $42.0 \mu \mathrm{eqL} \mathrm{L}^{-1}$, respectively, which were even higher than those at stations in the eastern TP, e.g., Lijiang $\left(11.4 \mu \mathrm{eq} \mathrm{L}^{-1}\right)$ and Lhasa (14.3 $\mu \mathrm{eqL} \mathrm{L}^{-1}$ ) (Table 2). Meanwhile, compared to Lijiang and Lhasa, Ngari Station and Muztagh Ata had lower annual precipitation rates of 124.6 and $213.6 \mathrm{~mm} \mathrm{yr}^{-1}$ (Table 2). Therefore, compared to the eastern TP, the western TP had relatively lower inorganic $\mathrm{N}$ deposition, probably due to its lower precipitation amount rather than its comparable inorganic $\mathrm{N}$ concentration in precipitation.

Wet deposition of inorganic $\mathrm{N}$ for the entire TP was much lower than that in northern and southern China (Table 3). The average wet deposition of atmospheric inorganic $\mathrm{N}$ (sum of $\mathrm{NH}_{4}^{+}-\mathrm{N}$ and $\mathrm{NO}_{3}^{-}-\mathrm{N}$ ) in the TP was estimated to be $1.58 \mathrm{~kg} \mathrm{Nha}^{-1} \mathrm{yr}^{-1}$. This was much lower than the inorganic $\mathrm{N}$ wet deposition at the cities in both northern and southern China, e.g., Beijing, Tianjin, Tangshan, Dalian, Nanjing, Hangzhou, Ningbo, Shanghai, Shenzhen, and Guiyang (Table 3). Moreover, the inorganic $\mathrm{N}$ wet deposition in the TP was also lower than that in the forest ecosystems of eastern China, e.g., Tieshanping, Luchongguan, Leigongshan, Caijiatang, and Liuxihe (Table 3). Overall, compared to eastern China, the TP had relatively lower inorganic $\mathrm{N}$ wet deposition, probably for the following two reasons. Firstly, except for Southeast Tibet Station and Lijiang, most N observation sites in the TP are located in typical arid and semi-arid regions, with annual precipitation ranging from $124.6 \mathrm{mmyr}^{-1}$ at Ngari Station to $582 \mathrm{mmyr}^{-1}$ at Biru. Compared to this, annual precipitation rates at sites in eastern 


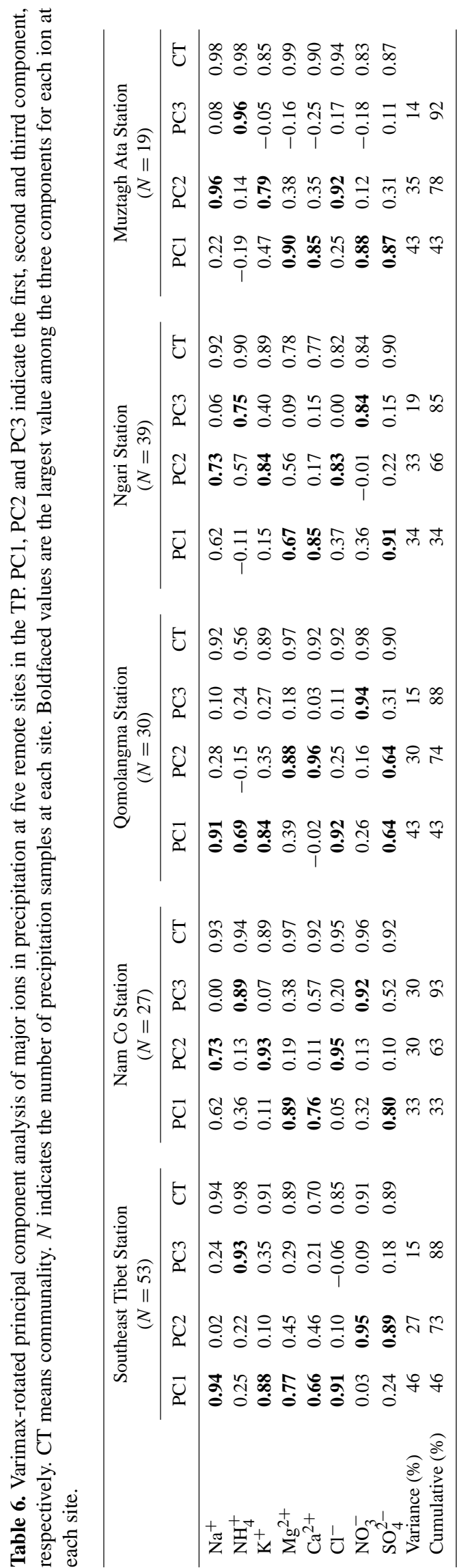

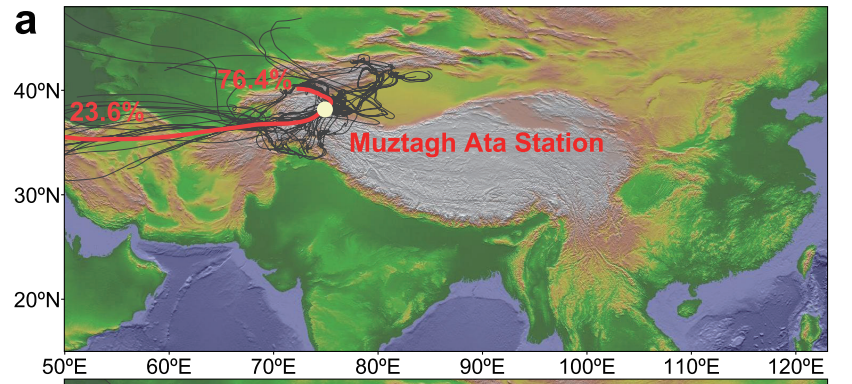
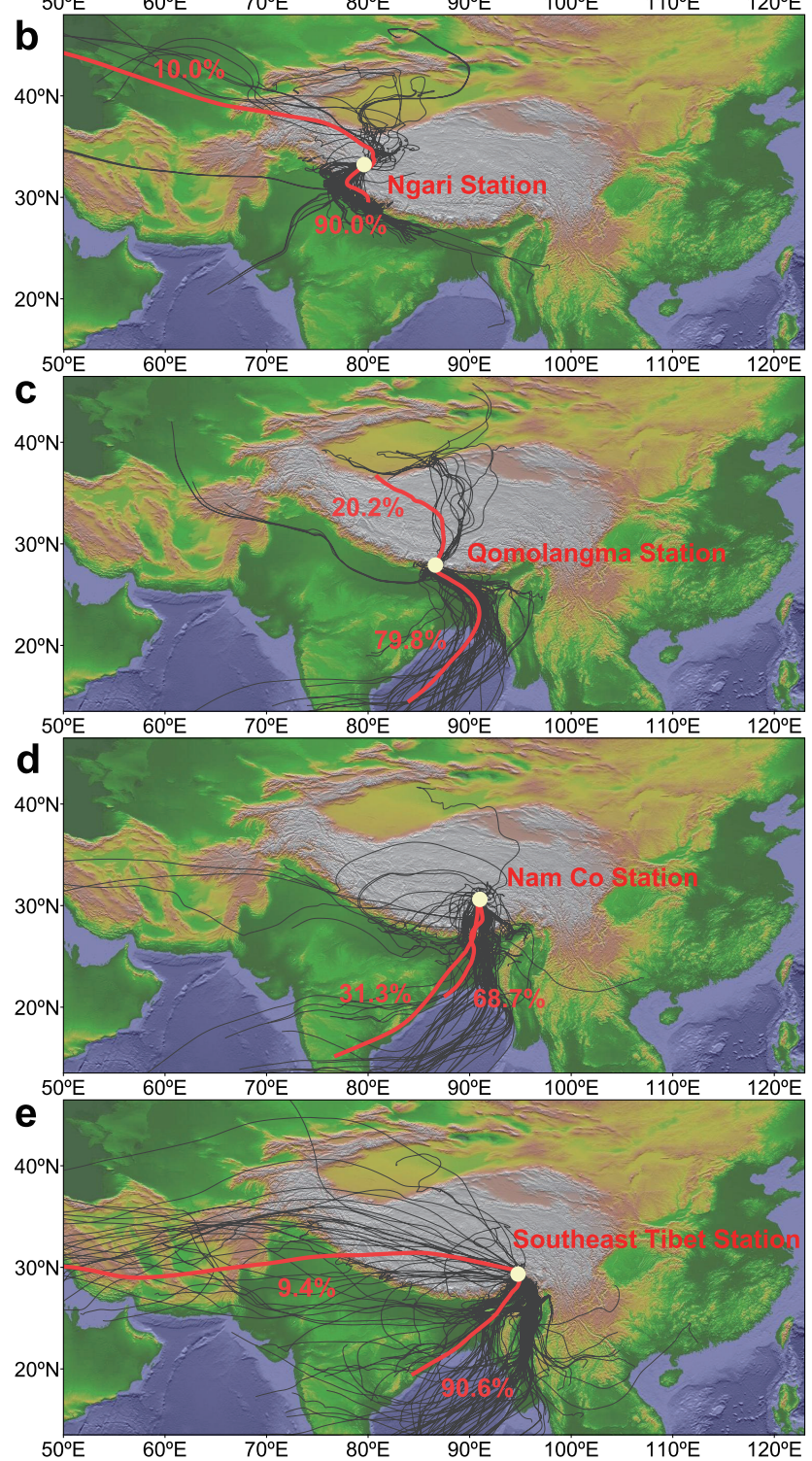

Figure 5. Seven-day backward trajectories at five remote sites in the TP. Black lines show the backward trajectories calculated at $6 \mathrm{~h}$ intervals (00:00, 06:00, 12:00, 18:00 UTC) on sampling days, with an arrival height of $500 \mathrm{~m}$ above the ground. Red lines show the clustering trajectories. 
China are much higher, particularly in southern China, where annual precipitation ranges from $825.5 \mathrm{~mm} \mathrm{yr}^{-1}$ at Shanghai to $1769 \mathrm{~mm} \mathrm{yr}^{-1}$ at Shenzhen (Table 3). Secondly, the average annual concentration of inorganic $\mathrm{N}\left(\mathrm{NH}_{4}^{+}-\mathrm{N}\right.$ and/or $\mathrm{NO}_{3}^{-}-\mathrm{N}$ ) in precipitation in the TP was much lower than that in eastern China, especially in cities in northern China (Table 2). This is probably because the effects of anthropogenic activities in eastern China are much more intense than those in the TP, which has an average altitude exceeding $4000 \mathrm{~m}$ above sea level and is referred to as "the third pole" (Qiu, 2008; Yao et al., 2012).

\subsection{Source assessment of atmospheric inorganic $N$ wet deposition in the TP}

To analyze the source contributions of major ion wet deposition, EF was applied using $\mathrm{Na}$ and $\mathrm{Ca}$ as a reference element for seawater and continental crust, respectively. Here, $\mathrm{Na}$ and $\mathrm{Ca}$ in precipitation in the TP were hypothesized as mainly coming from seawater and continental crust, respectively. This assumption was partly confirmed by the results of principal component analysis in this study (Table 6). Principal component analysis shows that the variances of $\mathrm{Ca}^{2+}$ and $\mathrm{Na}^{+}$were represented by different components at four of five sites (except Southeast Tibet Station), indicating a different source of $\mathrm{Ca}^{2+}$ and $\mathrm{Na}^{+}$in precipitation in the TP (Table 6). Moreover, $\mathrm{Na}^{+}$and $\mathrm{Cl}^{-}$were mainly explained by the same component at all sites. This indicates that $\mathrm{Na}^{+}$and $\mathrm{Cl}^{-}$were likely contributed by the same source: sea salt (Table 6). This assumption was also confirmed by the relatively high Pearson correlation between $\mathrm{Na}^{+}$and $\mathrm{Cl}^{-}$at all five sites (Table S1 in the Supplement). At Southeast Tibet Station, both $\mathrm{Ca}^{2+}$ and $\mathrm{Na}^{+}$variances were mostly represented by the first component (Table 6). This probably because south Asia is also an important source of dust aerosols in the southeastern TP during the during the monsoon period (Zhao et al., 2013).

$\mathrm{EF}$ analysis results showed that, at all the five sites, both $\mathrm{NH}_{4}^{+}$and $\mathrm{NO}_{3}^{-}$in precipitation were mainly contributed by anthropogenic sources (Table 5). This was also confirmed by principal component analysis. Different with $\mathrm{Ca}^{2+}$ and $\mathrm{Na}^{+}$, $\mathrm{NH}_{4}^{+}$variances were mainly represented by the third component at four of five sites (except for Qomolangma Station) (Table 6). Except for Muztagh Ata Station, at the other four stations, $\mathrm{NO}_{3}^{-}$variances were also represented by a different component than that of $\mathrm{Ca}^{2+}$ and $\mathrm{Na}^{+}$variances (Table 6). This indicates that the source of inorganic $\mathrm{N}$ wet deposition was probably different with the sources of $\mathrm{Ca}^{2+}$ or $\mathrm{Na}^{+}$wet deposition. Meanwhile, at all five sites, $\mathrm{Na}$ and $\mathrm{Ca}$ mainly came from seawater and continental crust, respectively. Therefore, inorganic $\mathrm{N}$ wet deposition at the five sites in the TP was mainly influenced by anthropogenic activities.

We applied backward trajectory analysis to identify the long-range transport of atmospheric inorganic $\mathrm{N}$ wet deposition at the five sites in the TP (Fig. 5). There is large spatial heterogeneity of air mass transport pathways across the five sites. At Muztagh Ata Station, wet deposition was mainly transported from central Asia and the Middle East (Fig. 5a). This is probably because Muztagh Ata Station is located in the northwestern TP, which is almost completely controlled by westerlies rather than the Indian monsoon (Yao et al., 2013). Thus, anthropogenic activities in central Asia and the Middle East are the principal source of the inorganic $\mathrm{N}$ wet deposition in the northwestern TP. Except for Muztagh Ata Station, inorganic $\mathrm{N}$ wet deposition at the other four sites was probably transported by Indian monsoon (Fig. 5be). At Ngari Station, $90.0 \%$ of wet deposition was transported from Nepal and northern India via the Indian monsoon, and $10.0 \%$ of wet deposition came from central Asia and Qaidam Basin via westerlies (Fig. 5b). At Qomolangma Station and Nam Co Station, inorganic N wet deposition was mainly influenced by the anthropogenic activities in northeastern India and Bangladesh (Fig. 5c and d). At Southeast Tibet Station, $90.6 \%$ of wet deposition was transported from India, Bangladesh and Myanmar by Indian monsoon, and the other $9.4 \%$ came from the western TP and the Middle East (Fig. 5e). Therefore, inorganic $\mathrm{N}$ wet deposition at these four stations principally was influenced by the anthropogenic $\mathrm{N}$ emissions in south Asia (e.g., India). Actually, after China and the United States, India has been the third largest producer and consumer of fertilizers due to intensification of agriculture, resulting in high anthropogenic $\mathrm{N}$ emissions (Aneja et al., 2012). For instance, ammonia $\left(\mathrm{NH}_{3}\right)$ emissions from livestock and fertilizer applications in India in 2003 was estimated as 1705 and $1697 \mathrm{Gg} \mathrm{yr}^{-1}$ $\left(\mathrm{Gg}=10^{9} \mathrm{~g}\right.$ ), respectively (Aneja et al., 2012). Moreover, in India, field burning of crop residue (FBCR) is another critical anthropogenic activity leading to $\mathrm{N}$ emissions. In 2010, $6300 \mathrm{Gg}$ of dry biomass are estimated to have been subjected to FBCR in India, resulting in $350 \mathrm{Gg} \mathrm{N}$ emissions (Sahai et al., 2011). Besides the Indian monsoon, biomass-burning emissions in south Asia could be across the Himalayas and transported to the TP by the mountain-valley wind (Cong et al., 2015).

\subsection{Comparison of inorganic $N$ wet deposition in the TP with previous estimations}

Long-term data set series of $\mathrm{N}$ deposition have been established based on observations (Lu and Tian, 2007, 2014, 2015) or model simulations (Dentener et al., 2006). These data sets have been used to estimate global or regional $\mathrm{N}$ deposition (Dentener et al., 2006; Lu and Tian, 2007) and drive ecosystem models to examine the ecological effects of elevated $\mathrm{N}$ deposition (Lu and Tian, 2013). Thus, reliable $\mathrm{N}$ deposition data sets are prerequisites for $\mathrm{N}$ deposition estimation or driving ecosystem models. Here, the estimation of $\mathrm{N}$ wet deposition in the TP based on our field observations is compared with previous estimations via limited observations or simulations. 
Lu and Tian (2007) estimated the inorganic N wet deposition as ranging from $4.16 \mathrm{~kg} \mathrm{Nha}^{-1} \mathrm{yr}^{-1}$ in the Tibet Autonomous Region (in the western TP) to $4.76 \mathrm{~kg} \mathrm{Nha}^{-1} \mathrm{yr}^{-1}$ in Qinghai Province (in the eastern TP). Recently, Jia et al. (2014) estimated the inorganic $\mathrm{N}$ wet deposition during the 2000s as ranging from $6.11 \mathrm{~kg} \mathrm{Nha}^{-1} \mathrm{yr}^{-1}$ in the $\mathrm{Ti}^{-}$ bet Autonomous Region to $7.87 \mathrm{~kg} \mathrm{Nha}^{-1} \mathrm{yr}^{-1}$ in Qinghai Province. Those estimations were even much higher than the highest record of inorganic $\mathrm{N}$ wet deposition observations in the TP (3.08 $\mathrm{kg} \mathrm{Nha}^{-1} \mathrm{yr}^{-1}$ at Biru during 2006-2007) (Table 3). In this study, combing in situ measurements at five sites in this study and seven sites in previous studies (Table 2), the average wet deposition of atmospheric $\mathrm{NH}_{4}^{+}-\mathrm{N}$, $\mathrm{NO}_{3}^{-}-\mathrm{N}$, and inorganic $\mathrm{N}$ in the TP were estimated to be $1.06,0.51$, and $1.58 \mathrm{~kg} \mathrm{Nha}^{-1} \mathrm{yr}^{-1}$, respectively. According to our study, both Lu and Tian (2007) and Jia et al. (2014) highly overestimated inorganic $\mathrm{N}$ wet deposition in the TP, likely for the following two reasons. Firstly, compared to our study, previous regional-scale estimations used far fewer in situ measurement sites. For example, there were only four sites in the Tibet Autonomous Region and one site in Qinghai Province used in the estimation of Jia et al. (2014). Such limited field observations probably led to large uncertainty in the conclusions drawn regarding inorganic $\mathrm{N}$ wet deposition in the entire TP. Secondly, the kriging interpolation technique was used in both Lu and Tian (2007) and Jia et al. (2014) to estimate the spatial pattern of inorganic $\mathrm{N}$ wet deposition in China. However, observation sites are sparsely distributed in the TP, and the estimation of inorganic $\mathrm{N}$ wet deposition in the TP is largely influenced by $\mathrm{N}$ deposition observations in the surrounding regions of much lower altitude. The average altitude of the TP is above $4000 \mathrm{~m}$, where both the climate and anthropogenic activities are substantially different with those in lower-altitude areas. For example, the average inorganic $\mathrm{N}$ wet deposition was $1.58 \mathrm{~kg} \mathrm{Nha}^{-1} \mathrm{yr}^{-1}$, which was much lower than that in northern and southern China (Table 3). The interpolations at the national scale in Lu and Tian (2007) and Jia et al. (2014) likely overestimated the regional inorganic $\mathrm{N}$ wet deposition in the TP. In addition, we also estimated the inorganic $\mathrm{N}$ wet deposition for the entire TP using kriging interpolation, but only based on the site-scale in situ measurements in the TP (12 sites, including 5 sites in this study and 7 sites in previous field observations), rather than the observations in the surrounding regions of much lower altitude. The inorganic $\mathrm{N}$ wet deposition for the entire TP estimation based on the kriging interpolation in our study is $1.56 \mathrm{~kg} \mathrm{Nha}^{-1} \mathrm{yr}^{-1}$ (Fig. S1 and spatial data as a NetCDF file in the Supplement), which is much lower than that in previous interpolation studies (Lu and Tian, 2007; Jia et al., 2014) but is comparable with the averaged inorganic $\mathrm{N}$ wet deposition among the 12 sites $\left(1.58 \mathrm{~kg} \mathrm{~N} \mathrm{ha}^{-1} \mathrm{yr}^{-1}\right)$ (Table 2).

Atmospheric chemistry transport models are commonly used to calculate current and future $\mathrm{N}$ deposition. Dentener et al. (2006) used 23 atmospheric chemistry transport mod- els to assess both global and regional $\mathrm{N}$ deposition. Compared to observation records, Dentener et al. (2006) underestimated inorganic $\mathrm{N}$ wet deposition over the whole of China (Lu and Tian, 2007), but overestimated it over the TP. According to Dentener et al. (2006), the $\mathrm{NH}_{4}^{+}-\mathrm{N}, \mathrm{NO}_{3}^{-}-\mathrm{N}$, and inorganic $\mathrm{N}$ wet deposition in the TP are 1.97, 0.99, and $2.96 \mathrm{~kg} \mathrm{Nha}^{-1} \mathrm{yr}^{-1}$, respectively - nearly double that of $\mathrm{N}$ deposition estimated in our study. Based on site-scale in situ measurements, we provide a more accurate regional-scale estimation of inorganic $\mathrm{N}$ wet deposition in the TP, which can be used as background information in studies focusing on the responses of alpine ecosystems to elevated $\mathrm{N}$ deposition. Besides assessment of $\mathrm{N}$ deposition, $\mathrm{N}$ deposition simulated by atmospheric chemistry transport models is usually used to drive large-scale ecosystem models for integrated ecosystem assessment (Xu-Ri et al., 2012; Zaehle, 2013). The ecological effects of $\mathrm{N}$ addition are probably influenced not only by the quantity of $\mathrm{N}$ deposition but also by the proportions of each component, e.g., the $\mathrm{NH}_{4}^{+}-\mathrm{N}: \mathrm{NO}_{3}^{-}-\mathrm{N}$ ratio. For example, in African savannas, plants demonstrate $\mathrm{N}$ uptake preference, which is likely influenced by the $\mathrm{NH}_{4}^{+}-\mathrm{N}$ : $\mathrm{NO}_{3}^{-}-\mathrm{N}$ ratio in their native habitats (Wang and Macko, 2011). However, in most current $\mathrm{N}$ fertilization experiments, the $\mathrm{N}$ forms of fertilizer are $\mathrm{NH}_{4} \mathrm{NO}_{3}, \mathrm{NH}_{4}^{+}-\mathrm{N}$ or $\mathrm{NO}_{3}^{-}-\mathrm{N}$ (Liu and Greaver, 2009), with the $\mathrm{NH}_{4}^{+}-\mathrm{N}: \mathrm{NO}_{3}^{-}-\mathrm{N}$ ratio of $\mathrm{N}$ wet deposition at experimental sites not considered. Our work shows that the estimated $\mathrm{NH}_{4}^{+}-\mathrm{N}: \mathrm{NO}_{3}^{-}-\mathrm{N}$ ratio of inorganic $\mathrm{N}$ wet deposition in the TP is approximately $2: 1$, which is consistent with the modeled estimation of Dentener et al. (2006), but lower than the $\mathrm{NH}_{4}^{+}-\mathrm{N}: \mathrm{NO}_{3}^{-}-\mathrm{N}$ ratio of 2.5 in forest ecosystems in eastern China (Du et al., 2014). This $\mathrm{NH}_{4}^{+}-\mathrm{N}: \mathrm{NO}_{3}^{-}-\mathrm{N}$ ratio $(2: 1)$ is recommended to be considered when $\mathrm{N}$ fertilization experiments are conducted in alpine ecosystems in the TP.

\subsection{Uncertainty and recommendations}

Combining our in situ measurements at five remote sites and previous site-scale field observations, the inorganic $\mathrm{N}$ wet deposition in the TP was quantitatively assessed in this study. The assessment is conducive to accurately estimating $\mathrm{N}$ wet deposition for the entire nation of China, and it provides background information of $\mathrm{N}$ wet deposition for the studies focusing on the alpine ecological effects of elevated $\mathrm{N}$ deposition. Despite this, there are uncertainties in the estimation of $\mathrm{N}$ deposition in the TP for the following reasons. Firstly, total $\mathrm{N}$ deposition comprises wet deposition (in the form of precipitation) and dry deposition (in the form of gases and particles). Considering the whole of China, dry deposition contributes $30 \%$ to total inorganic $\mathrm{N}$ deposition (Lu and Tian, 2007, 2014, 2015). In northern China, this ratio is much higher, at $60 \%$ (Pan et al., 2012). However, in this study, we only estimated the inorganic $\mathrm{N}$ wet deposition in the TP, with the situation regarding dry deposition remaining unclear. Thus, investigation of $\mathrm{N}$ dry deposition is critical 
for assessing total $\mathrm{N}$ deposition in the TP. Secondly, the TP covers an area of about 2.57 million $\mathrm{km}^{2}$, occupying approximately one-fourth of the land area of China (Zhang et al., 2002). Precipitation in the TP is influenced by both the Indian monsoon and westerlies, leading to spatial variation in the origins of $\mathrm{N}$ wet deposition. Therefore, it is necessary to establish $\mathrm{N}$ wet deposition observation sites in different climatic zones. Thirdly, besides spatial heterogeneity, $\mathrm{N}$ deposition in the TP also possesses temporal heterogeneity. Inorganic $\mathrm{N}$ wet deposition in the TP has increased during recent decades, as recorded in ice cores (Hou et al., 2003; Kang et al., 2002a, b; Thompson et al., 2000; Zhao et al., 2011; Zheng et al., 2010) and sediment cores of alpine lakes (Choudhary et al., 2013; Hu et al., 2014). The long-term trend and interannual variability of inorganic $\mathrm{N}$ wet deposition in the TP cannot be quantitatively characterized by the short-term in situ measurements in this study. Overall, critical questions remain open regarding the quantitative understanding of $\mathrm{N}$ deposition in the TP. To deepen our understanding of $\mathrm{N}$ deposition in the TP, it is essential to perform long-term in situ measurements of $\mathrm{N}$ wet and dry deposition in various climate zones in the future.

\section{Conclusions}

Alpine ecosystems in the TP are sensitive to elevated $\mathrm{N}$ deposition, and the inorganic $\mathrm{N}$ deposition has been increasing since the mid-20th century. However, the amount of inorganic $\mathrm{N}$ wet deposition in the TP remains unclear, due to a paucity of in situ measurement. In this study, using stations in the TORP network, we conducted in situ measurements of major ion wet deposition at five remote sites, situated mainly in the central and western TP. Among the five sites, both $\mathrm{NH}_{4}^{+}-\mathrm{N}$ and $\mathrm{NO}_{3}^{-}-\mathrm{N}$ were mainly contributed by anthropogenic sources. Combining site-scale in situ measurements in our study and previous studies, the average wet deposition of atmospheric $\mathrm{NH}_{4}^{+}-\mathrm{N}, \mathrm{NO}_{3}^{-}-\mathrm{N}$, and inorganic $\mathrm{N}$ in the TP is estimated to be $1.06,0.51$, and $1.58 \mathrm{~kg} \mathrm{Nha}^{-1} \mathrm{yr}^{-1}$, respectively. Considering the entire TP, according to our results, previous regional-scale assessment has highly overestimated inorganic $\mathrm{N}$ wet deposition, either through simulations with atmospheric chemistry transport models (Dentener et al., 2006) or interpolations based on limited field observations for the whole of China (Jia et al., 2014; Lu and Tian, 2007). The $\mathrm{NH}_{4}^{+}-\mathrm{N}: \mathrm{NO}_{3}^{-}-\mathrm{N}$ ratio in precipitation in the TP was found to be approximately $2: 1$, which is consistent with model simulations (Dentener et al., 2006). To clarify the total $\mathrm{N}$ deposition in the TP more clearly, we recommend conducting long-term monitoring of both wet and dry deposition of $\mathrm{N}$ in various climate zones in the future work.

\section{The Supplement related to this article is available online} at doi:10.5194/acp-15-11683-2015-supplement.
Acknowledgements. We are grateful to the staff at the Southeast Tibet Observation and Research Station for the Alpine Environment, Chinese Academy of Sciences; Nam Co Monitoring and Research Station for Multisphere Interactions, Chinese Academy of Sciences; Qomolangma Atmospheric and Environmental Observation and Research Station, Chinese Academy of Sciences; Ngari Desert Observation and Research Station; and Muztagh Ata Westerly Observation and Research Station for their assistance in collecting the samples and providing the precipitation data. The authors acknowledge Da Wei, Dongxue Dai, Xiaodong Geng, Tenzin Tarchen, and Shan Lu for their contributions to the fieldwork. The authors acknowledge the constructive comments of the two anonymous referees, whose helpful feedback resulted in a greatly improved manuscript. This work was supported by the Strategic Priority Research Program - Climate Change: Carbon Budget and Related Issues, of the Chinese Academy of Sciences (XDA05050404-3-2, XDA05020402), and the National Natural Science Foundation of China (40605032, 40975096, 41175128).

Edited by: L. Zhang

\section{References}

Aneja, V. P., Schlesinger, W. H., Erisman, J. W., Behera, S. N., Sharma, M., and Battye, W.: Reactive nitrogen emissions from crop and livestock farming in India, Atmos. Environ., 47, 92103, doi:10.1016/j.atmosenv.2011.11.026, 2012.

Balasubramanian, R., Victor, T., and Chun, N.: Chemical and statistical analysis of precipitation in Singapore, Water. Air Soil Poll., 130, 451-456, doi:10.1023/A:1013801805621, 2001.

Balestrini, R., Polesello, S., and Sacchi, E.: Chemistry and isotopic composition of precipitation and surface waters in Khumbu valley (Nepal Himalaya): $\mathrm{N}$ dynamics of high elevation basins, Sci. Total. Environ., 485, 681-692, doi:10.1016/j.scitotenv.2014.03.096, 2014.

Basto, S., Thompson, K., Phoenix, G., Sloan, V., Leake, J., and Rees, M.: Long-term nitrogen deposition depletes grassland seed banks, Nat. Commun., 6, 6185, doi:10.1038/ncomms7185, 2015.

Canfield, D. E., Glazer, A. N., and Falkowski, P. G.: The evolution and future of Earth's nitrogen cycle, Science, 330, 192-196, doi:10.1126/science.1186120, 2010.

Cao, Y. Z., Wang, S. Y., Zhang, G., Luo, J. Y., and Lu, S. Y.: Chemical characteristics of wet precipitation at an urban site of Guangzhou, South China, Atmos. Res., 94, 462-469, doi:10.1016/j.atmosres.2009.07.004, 2009.

Chabas, A. and Lefevre, R. A.: Chemistry and microscopy of atmospheric particulates at Delos (Cyclades-Greece), Atmos. Environ., 34, 225-238, doi:10.1016/S1352-2310(99)00255-1, 2000.

Chen, X. Y. and Mulder, J.: Atmospheric deposition of nitrogen at five subtropical forested sites in South China, Sci. Total. Environ., 378, 317-330, doi:10.1016/j.scitotenv.2007.02.028, 2007.

Choudhary, P., Routh, J., and Chakrapani, G. J.: A 100-year record of changes in organic matter characteristics and productivity in Lake Bhimtal in the Kumaon Himalaya, NW India, J. Paleolimnol., 49, 129-143, doi:10.1007/s10933-012-9647-9, 2013.

Cong, Z. Y., Kawamura, K., Kang, S. C., and Fu, P. Q.: Penetration of biomass-burning emissions from South Asia through the Hi- 
malayas: new insights from atmospheric organic acids, Sci. Rep.Uk, 5, 9580, doi:10.1038/srep09580, 2015.

Dentener, F., Drevet, J., Lamarque, J. F., Bey, I., Eickhout, B., Fiore, A. M., Hauglustaine, D., Horowitz, L. W., Krol, M., Kulshrestha, U. C., Lawrence, M., Galy-Lacaux, C., Rast, S., Shindell, D., Stevenson, D., Van Noije, T., Atherton, C., Bell, N., Bergman, D., Butler, T., Cofala, J., Collins, B., Doherty, R., Ellingsen, K., Galloway, J., Gauss, M., Montanaro, V., Muller, J. F., Pitari, G., Rodriguez, J., Sanderson, M., Solmon, F., Strahan, S., Schultz, M., Sudo, K., Szopa, S., and Wild, O.: Nitrogen and sulfur deposition on regional and global scales: A multimodel evaluation, Global Biogeochem. Cycles, 20, GB4003, doi:10.1029/2005GB002672, 2006.

Ding, G. A., Xu, X. B., and Wang, S. F.: Database from the acid rain network of China meteorological administration and it's preliminary analyses, J. Appl. Meteorol. Sci., 15, 85-94, 2004 (in Chinese with English abstract).

Ding, M., Yao, F., Chen, J., Wang, X., and Yang, S.: Chemical characteristics of acidic precipitation in Tiantong, Zhejiang Province, Acta Scientiae Circumstantiae, 32, 2245-2252, 2012 (in Chinese with English abstract)

Du, E., Jiang, Y., Fang, J. Y., and de Vries, W.: Inorganic nitrogen deposition in China's forests: Status and characteristics, Atmos. Environ., 98, 474-482, doi:10.1016/j.atmosenv.2014.09.005, 2014.

Erisman, J. W., Galloway, J., Seitzinger, S., Bleeker, A., and Butterbach-Bahl, K.: Reactive nitrogen in the environment and its effect on climate change, Curr. Opin. Env. Sust., 3, 281-290, doi:10.1016/j.cosust.2011.08.012, 2011.

Erisman, J. W., Galloway, J. N., Seitzinger, S., Bleeker, A., Dise, N. B., Petrescu, A. M. R., Leach, A. M., and de Vries, W.: Consequences of human modification of the global nitrogen cycle, Philos. T. R. Soc. B, 368, 20130116, doi:10.1098/rstb.2013.0116, 2013.

Fagerli, H. and Aas, W.: Trends of nitrogen in air and precipitation: Model results and observations at EMEP sites in Europe, 1980-2003, Environ. Pollut., 154, 448-461, doi:10.1016/j.envpol.2008.01.024, 2008.

Fang, X. M., Han, Y. X., Ma, J. H., Song, L. C., Yang, S. L., and Zhang, X. Y.: Dust storms and loess accumulation on the Tibetan Plateau: A case study of dust event on 4 March 2003 in Lhasa, Chinese Sci. Bull., 49, 953-960, doi:10.1360/03wd0180, 2004.

Galloway, J. N., Townsend, A. R., Erisman, J. W., Bekunda, M., Cai, Z. C., Freney, J. R., Martinelli, L. A., Seitzinger, S. P., and Sutton, M. A.: Transformation of the nitrogen cycle: Recent trends, questions, and potential solutions, Science, 320, 889-892, doi:10.1126/science.1136674, 2008.

Gao, J. G., Zhang, Y. L., Liu, L. S., and Wang, Z. F.: Climate change as the major driver of alpine grasslands expansion and contraction: A case study in the Mt. Qomolangma (Everest) National Nature Preserve, southern Tibetan Plateau, Quatern. Int., 336, 108-116, doi:10.1016/j.quaint.2013.09.035, 2014.

Grigholm, B., Mayewski, P. A., Kang, S., Zhang, Y., Morgenstern, U., Schwikowski, M., Kaspari, S., Aizen, V., Aizen, E., Takeuchi, N., Maasch, K. A., Birkel, S., Handley, M., and Sneed, S.: Twentieth century dust lows and the weakening of the westerly winds over the Tibetan Plateau, Geophys. Res. Lett., 42, 2434-2441, doi:10.1002/2015g1063217, 2015
Gruber, N. and Galloway, J. N.: An Earth-system perspective of the global nitrogen cycle, Nature, 451, 293-296, doi:10.1038/nature06592, 2008.

Han, Y. X., Fang, X. M., Kang, S. C., Wang, H. J., and Kang, F. Q.: Shifts of dust source regions over central Asia and the Tibetan Plateau: Connections with the Arctic oscillation and the westerly jet, Atmos. Environ., 42, 2358-2368, doi:10.1016/j.atmosenv.2007.12.025, 2008.

Han, Y. X., Fang, M., Zhao, T. L., Bai, H. Z., Kang, S. C., and Song, L. C.: Suppression of precipitation by dust particles originated in the Tibetan Plateau, Atmos. Environ., 43, 568-574, doi:10.1016/j.atmosenv.2008.10.018, 2009.

Hou, S.: Chemical Characteristics of Precipitation at the Headwaters of the Ürümqi River in the Tianshan Mountains, Journal of Glaciology and Geocryology, 23, 80-84, 2001 (in Chinese with English abstract).

Hou, S. G., Qin, D. H., Zhang, D. Q., Kang, S. C., Mayewski, P. A., and Wake, C. P.: A 154a high-resolution ammonium record from the Rongbuk Glacier, north slope of Mt. Qomolangma (Everest), Tibet-Himal region, Atmos. Environ., 37, 721-729, doi:10.1016/S1352-2310(02)00582-4, 2003.

Hu, Z. J., Anderson, N. J., Yang, X. D., and McGowan, S.: Catchment-mediated atmospheric nitrogen deposition drives ecological change in two alpine lakes in SE Tibet, Glob. Change Biol., 20, 1614-1628, doi:10.1111/Gcb.12435, 2014.

Huang, J. P., Minnis, P., Yi, Y. H., Tang, Q., Wang, X., Hu, Y. X., Liu, Z. Y., Ayers, K., Trepte, C., and Winker, D.: Summer dust aerosols detected from CALIPSO over the Tibetan Plateau, Geophys. Res. Lett., 34, L18805, doi:10.1029/2007g1029938, 2007.

Huang, J. P., Wang, T. H., Wang, W. C., Li, Z. Q., and Yan, H. R.: Climate effects of dust aerosols over East Asian arid and semiarid regions, J. Geophys. Res.-Atmos., 119, 11398-11416, doi:10.1002/2014jd021796, 2014.

Huang, K., Zhuang, G. S., Xu, C., Wang, Y., and Tang, A. H.: The chemistry of the severe acidic precipitation in Shanghai, China, Atmos. Res., 89, 149-160, doi:10.1016/j.atmosres.2008.01.006, 2008.

Huang, Y. L., Wang, Y. L., and Zhang, L. P.: Long-term trend of chemical composition of wet atmospheric precipitation during 1986-2006 at Shenzhen City, China, Atmos. Environ., 42, 37403750, doi:10.1016/j.atmosenv.2007.12.063, 2008.

Jia, J.: Study of atmospheric wet deposition of nitrogen in Tibetan Plateau, Master, Tibet University, 2008 (in Chinese with English abstract).

Jia, Y., Yu, G., He, N., Zhan, X., Fang, H., Sheng, W., Zuo, Y., Zhang, D., and Wang, Q.: Spatial and decadal variations in inorganic nitrogen wet deposition in China induced by human activity, Sci. Rep.-UK, 4, 3763, doi:10.1038/srep03763, 2014.

Kang, S., Mayewski, P. A., Qin, D., Yan, Y., Hou, S., Zhang, D., Ren, J., and Kruetz, K.: Glaciochemical records from a Mt. Everest ice core: relationship to atmospheric circulation over Asia, Atmos. Environ., 36, 3351-3361, doi:10.1016/S13522310(02)00325-4, 2002a.

Kang, S. C., Mayewski, P. A., Qin, D. H., Yan, Y. P., Zhang, D. Q., Hou, S. G., and Ren, J. W.: Twentieth century increase of atmospheric ammonia recorded in Mount Everest ice core, J. Geophys. Res.-Atmos., 107, 4595, doi:10.1029/2001jd001413, 2002b. 
Kang, S. C., Zhang, Y. L., Zhang, Y. J., Grigholm, B., Kaspari, S., Qin, D. H., Ren, J. W., and Mayewski, P.: Variability of atmospheric dust loading over the central Tibetan Plateau based on ice core glaciochemistry, Atmos. Environ., 44, 2980-2989, doi:10.1016/j.atmosenv.2010.05.014, 2010.

Kaspari, S., Mayewski, P., Kang, S., Sneed, S., Hou, S., Hooke, R., Kreutz, K., Introne, D., Handley, M., Maasch, K., Qin, D., and Ren, J.: Reduction in northward incursions of the South Asian monsoon since approximate to 1400 AD inferred from a Mt. Everest ice core, Geophys. Res. Lett., 34, L16701, doi:10.1029/2007g1030440, 2007.

Keene, W. C., Pszenny, A. A. P., Galloway, J. N., and Hawley, M. E.: Sea-salt corrections and interpretation of constituent ratios in marine precipitation, J. Geophys. Res.-Atmos., 91, 6647-6658, doi:10.1029/Jd091id06p06647, 1986.

Kulshrestha, U. C., Sarkar, A. K., Srivastava, S. S., and Parashar, D. C.: Investigation into atmospheric deposition through precipitation studies at New Delhi (India), Atmos. Environ., 30, 41494154, doi:10.1016/1352-2310(96)00034-9, 1996.

Kulshrestha, U. C., Kulshrestha, M. J., Sekar, R., Sastry, G. S. R., and Vairamani, M.: Chemical characteristics of rainwater at an urban site of south-central India, Atmos. Environ., 37, 30193026, doi:10.1016/S1352-2310(03)00266-8, 2003.

Lan, Z., Jenerette, G. D., Zhan, S., Li, W., Zheng, S., and Bai, Y.: Testing the scaling effects and mechanisms of $\mathrm{N}$-induced biodiversity loss: Evidence from a decade-long grassland experiment, J. Ecol., 103, 750-760, doi:10.1111/1365-2745.12395, 2015.

Lehmann, C. M. B., Bowersox, V. C., and Larson, S. M.: Spatial and temporal trends of precipitation chemistry in the United States, 1985-2002, Environ. Pollut., 135, 347-361, doi:10.1016/j.envpol.2004.11.016, 2005.

Li, C., Kang, S. C., Zhang, Q. G., and Kaspari, S.: Major ionic composition of precipitation in the Nam Co region, Central Tibetan Plateau, Atmos. Res., 85, 351-360, doi:10.1016/j.atmosres.2007.02.006, 2007.

Li, M., Ma, Y., Ishikawa, H., Ma, W., Sun, F., Wang, Y., and Zhu, Z.: Characteristics of micrometeorological elements near surface and soil on the northern slope of Mt. Qomolangma area, Plateau Meteorology, 26, 1263-1268, 2007 (in Chinese with English abstract).

Li, Z. J., Li, Z. X., Wang, T. T., Gao, Y., Cheng, A. F., Guo, X. Y., Guo, R., Jia, B., Song, Y. X., Han, C. T., and Theakstone, W.: Composition of wet deposition in the central Qilian Mountains, China, Environ. Earth Sci., 73, 7315-7328, doi:10.1007/s12665014-3907-0, 2015.

Liu, B., Kang, S. C., Sun, J. M., Zhang, Y. L., Xu, R., Wang, Y. J., Liu, Y. W., and Cong, Z. Y.: Wet precipitation chemistry at a high-altitude site (3326 $\mathrm{m}$ a.s.1.) in the southeastern Tibetan Plateau, Environ. Sci. Pollut. R., 20, 5013-5027, doi:10.1007/s11356-012-1379-x, 2013.

Liu, L. L. and Greaver, T. L.: A review of nitrogen enrichment effects on three biogenic GHGs: the $\mathrm{CO}_{2}$ sink may be largely offset by stimulated $\mathrm{N}_{2} \mathrm{O}$ and $\mathrm{CH}_{4}$ emission, Ecol. Lett., 12, 11031117, doi:10.1111/j.1461-0248.2009.01351.x, 2009.

Liu, X. J., Duan, L., Mo, J. M., Du, E. Z., Shen, J. L., Lu, X. K., Zhang, Y., Zhou, X. B., He, C. N., and Zhang, F. S.: Nitrogen deposition and its ecological impact in China: An overview, Environ. Pollut., 159, 2251-2264, doi:10.1016/j.envpol.2010.08.002, 2011.
Liu, X. J., Zhang, Y., Han, W. X., Tang, A. H., Shen, J. L., Cui, Z. L., Vitousek, P., Erisman, J. W., Goulding, K., Christie, P., Fangmeier, A., and Zhang, F. S.: Enhanced nitrogen deposition over China, Nature, 494, 459-462, doi:10.1038/nature11917, 2013.

Liu, Y. H., Dong, G. R., Li, S., and Dong, Y. X.: Status, causes and combating suggestions of sandy desertification in Qinghai-Tibet Plateau, Chinese Geogr. Sci., 15, 289-296, doi:10.1007/s11769005-0015-9, 2005.

Liu, Y. W., Xu-Ri, Xu, X. L., Wei, D., Wang, Y. H., and Wang, Y. S.: Plant and soil responses of an alpine steppe on the Tibetan Plateau to multi-level nitrogen addition, Plant Soil, 373, 515529, doi:10.1007/s11104-013-1814-x, 2013.

Lu, C. Q. and Tian, H. Q.: Spatial and temporal patterns of nitrogen deposition in China: Synthesis of observational data, J. Geophys. Res.-Atmos., 112, D22S05, doi:10.1029/2006JD007990, 2007.

Lu, C. Q. and Tian, H. Q.: Net greenhouse gas balance in response to nitrogen enrichment: perspectives from a coupled biogeochemical model, Glob. Change Biol., 19, 571-588, doi:10.1111/gcb.12049, 2013.

Lu, C. Q. and Tian, H. Q.: Half-century nitrogen deposition increase across China: A gridded time-series data set for regional environmental assessments, Atmos. Environ., 97, 68-74, doi:10.1016/j.atmosenv.2014.07.061, 2014.

Lu, C. Q. and Tian, H. Q.: Reply to "Comments on 'Half-century nitrogen deposition increase across China: A gridded time-series dataset for regional environmental assessments", Atmos. Environ., 101, 352-353, doi:10.1016/j.atmosenv.2014.11.032, 2015.

Lu, X. W., Li, L. Y., Li, N., Yang, G., Luo, D. C., and Chen, J. H.: Chemical characteristics of spring rainwater of Xi'an city, NW China, Atmos. Environ., 45, 5058-5063, doi:10.1016/j.atmosenv.2011.06.026, 2011.

Ma, Y. M., Kang, S. C., Zhu, L. P., Xu, B. Q., Tian, L. D., and Yao, T. D.: Tibetan Observation and Research Platform-atmosphereland interaction over a heterogeneous landscape, B. Am. Meteorol. Soc., 89, 1487-1492, doi:10.1175/2008bams2545.1, 2008.

Ma, Z., Ma, M. J., Baskin, J. M., Baskin, C. C., Li, J. Y., and Du, G. Z.: Responses of alpine meadow seed bank and vegetation to nine consecutive years of soil fertilization, Ecol. Eng., 70, 92101, doi:10.1016/j.ecoleng.2014.04.009, 2014.

Mao, R., Gong, D. Y., Shao, Y. P., Wu, G. J., and Bao, J. D.: Numerical analysis for contribution of the Tibetan Plateau to dust aerosols in the atmosphere over the East Asia, Sci. China Earth Sci., 56, 301-310, doi:10.1007/s11430-012-4460-x, 2013.

Migliavacca, D., Teixeira, E. C., Wiegand, F., Machado, A. C. M., and Sanchez, J.: Atmospheric precipitation and chemical composition of an urban site, Guaiba hydrographic basin, Brazil, Atmos. Environ., 39, 1829-1844, doi:10.1016/j.atmosenv.2004.12.005, 2005.

Morino, Y., Ohara, T., Kurokawa, J., Kuribayashi, M., Uno, I., and Hara, H.: Temporal variations of nitrogen wet deposition across Japan from 1989 to 2008, J. Geophys. Res.-Atmos., 116, D06307, doi:10.1029/2010jd015205, 2011.

Okay, C., Akkoyunlu, B. O., and Tayanc, M.: Composition of wet deposition in Kaynarca, Turkey, Environ. Pollut., 118, 401-410, doi:10.1016/S0269-7491(01)00292-5, 2002.

Pan, Y. P., Wang, Y. S., Tang, G. Q., and Wu, D.: Wet and dry deposition of atmospheric nitrogen at ten sites in Northern China, Atmos. Chem. Phys., 12, 6515-6535, doi:10.5194/acp-12-65152012, 2012. 
Pinder, R. W., Davidson, E. A., Goodale, C. L., Greaver, T. L., Herrick, J. D., and Liu, L. L.: Climate change impacts of US reactive nitrogen, P. Natl. Acad. Sci. USA, 109, 7671-7675, doi:10.1073/pnas.1114243109, 2012.

Puxbaum, H., Simeonov, V., Kalina, M., Tsakovski, S., Loffler, H., Heimburger, G., Biebl, P., Weber, A., and Damm, A.: Longterm assessment of the wet precipitation chemistry in Austria (1984-1999), Chemosphere, 48, 733-747, doi:10.1016/S00456535(02)00125-X, 2002.

Qiu, J.: The third pole, Nature, 454, 393-396, doi:10.1038/454393a, 2008.

R Core Team: R: A language and environment for statistical computing, R Foundation for Statistical Computing, Vienna, Austria, 2015.

Rodhe, H. and Granat, L.: An evaluation of sulfate in European precipitation 1955-1982, Atmos. Environ., 18, 2627-2639, doi:10.1016/0004-6981(84)90327-5, 1984.

Safai, P. D., Rao, P. S. P., Mornin, G. A., All, K., Chate, D. M., and Praveen, P. S.: Chemical composition of precipitation during 1984-2002 at Pune, India, Atmos. Environ., 38, 1705-1714, doi:10.1016/j.atmosenv.2003.12.016, 2004.

Sahai, S., Sharma, C., Singh, S. K., and Gupta, P. K.: Assessment of trace gases, carbon and nitrogen emissions from field burning of agricultural residues in India, Nutr. Cycl. Agroecosys., 89, 143 157, doi:10.1007/s10705-010-9384-2, 2011.

Shen, W. J., Ren, H. L., Jenerette, G. D., Hui, D. F., and Ren, H.: Atmospheric deposition and canopy exchange of anions and cations in two plantation forests under acid rain influence, Atmos. Environ., 64, 242-250, doi:10.1016/j.atmosenv.2012.10.015, 2013.

Sheng, W. P., Yu, G. R., Jiang, C. M., Yan, J. H., Liu, Y. F., Wang, S. L., Wang, B., Zhang, J. H., Wang, C. K., Zhou, M., and Jia, B. R.: Monitoring nitrogen deposition in typical forest ecosystems along a large transect in China, Environ. Monit. Assess., 185, 833-844, doi:10.1007/s10661-012-2594-0, 2013.

Shi, Y. L., Cui, S. H., Ju, X. T., Cai, Z. C., and Zhu, Y. G.: Impacts of reactive nitrogen on climate change in China, Sci. Rep.-UK, 5, 8118, doi:10.1038/Srep08118, 2015.

Tang, J., Xue, H., Yu, X., Cheng, H., Xu, X., Zhang, X., and Ji, J.: The preliminary study on chemical characteristics of precipitation at Mt. Waliguan, Acta Scientiae Circumstantiae, 20, 420 425, 2000 (in Chinese with English abstract).

Taylor, S. R.: Abundance of chemical elements in the continental crust - a new table, Geochim. Cosmochim. Ac., 28, 1273-1285, doi:10.1016/0016-7037(64)90129-2, 1964.

Thompson, L. G., Yao, T., Mosley-Thompson, E., Davis, M. E., Henderson, K. A., and Lin, P. N.: A high-resolution millennial record of the South Asian Monsoon from Himalayan ice cores, Science, 289, 1916-1919, doi:10.1126/science.289.5486.1916, 2000.

Tripathee, L., Kang, S. C., Huang, J., Sillanpaa, M., Sharma, C. M., Luthi, Z. L., Guo, J. M., and Paudyal, R.: Ionic composition of wet precipitation over the southern slope of central Himalayas, Nepal, Environ. Sci. Pollut. R., 21, 2677-2687, doi:10.1007/s11356-013-2197-5, 2014.

Tu, J., Wang, H. S., Zhang, Z. F., Jin, X., and Li, W. Q.: Trends in chemical composition of precipitation in Nanjing, China, during 1992-2003, Atmos. Res., 73, 283-298, doi:10.1016/j.atmosres.2004.11.002, 2005.
Turekian, K. K.: Oceans, Prentice-Hall, New Jersey, United States, 1968.

Wang, L. X. and Macko, S. A.: Constrained preferences in nitrogen uptake across plant species and environments, Plant Cell Environ., 34, 525-534, doi:10.1111/j.1365-3040.2010.02260.x, 2011.

Wang, N. L., Yao, T. D., Thompson, L. G., and Davis, M. E.: Indian monsoon and North Atlantic Oscillation signals reflected by $\mathrm{Cl}^{-}$and $\mathrm{Na}^{+}$in a shallow ice core from Dasuopu Glacier, Xixabangma, Himalaya, Ann. Glaciol., 35, 273-277, doi:10.3189/172756402781816825, 2002.

Wang, P. L., Yao, T. D., Tian, L. D., Wu, G. J., Li, Z., and Yang, W.: Recent high-resolution glaciochemical record from a Dasuopu firn core of middle Himalayas, Chinese Sci. Bull., 53, 418-425, doi:10.1007/s11434-008-0098-7, 2008.

Wang, Y., Ma, Y., Zhu, Z., and Li, M.: Variation characteristics of meteorological elements in near surface layer over the Lulang valley of southeastern Tibetan Plateau, Plateau Meteorol., 29, 63-69, 2010 (in Chinese with English abstract).

Wang, Y. Q., Zhang, X. Y., and Draxler, R. R.: TrajStat: GISbased software that uses various trajectory statistical analysis methods to identify potential sources from long-term air pollution measurement data, Environ. Model. Soft., 24, 938-939, doi:10.1016/j.envsoft.2009.01.004, 2009.

Xia, X. G., Wang, P. C., Wang, Y. S., Li, Z. Q., Xin, J. Y., Liu, J., and Chen, H. B.: Aerosol optical depth over the Tibetan Plateau and its relation to aerosols over the Taklimakan Desert, Geophys Res Lett, 35, L16804, doi:10.1029/2008g1034981, 2008.

Xiao, H. W., Xiao, H. Y., Long, A. M., Wang, Y. L., and Liu, C. Q.: Chemical composition and source apportionment of rainwater at Guiyang, SW China, J. Atmos. Chem., 70, 269-281, doi:10.1007/s10874-013-9268-3, 2013.

Xu, H., Bi, X. H., Feng, Y. C., Lin, F. M., Jiao, L., Hong, S. M., Liu, W. G., and Zhang, X. Y.: Chemical composition of precipitation and its sources in Hangzhou, China, Environ. Monit. Assess., 183, 581-592, doi:10.1007/s10661-011-1963-4, 2011.

Xu-Ri, Prentice, I. C., Spahni, R., and Niu, H. S.: Modelling terrestrial nitrous oxide emissions and implications for climate feedback, New. Phytol., 196, 472-488, doi:10.1111/j.14698137.2012.04269.x, 2012.

Xu, X. L., Wanek, W., Zhou, C. P., Richter, A., Song, M. H., Cao, G. M., Ouyang, H., and Kuzyakov, Y.: Nutrient limitation of alpine plants: Implications from leaf $\mathrm{N}$ : P stoichiometry and leaf $\delta^{15} \mathrm{~N}$, J. Plant Nutr. Soil Sc., 177, 378-387, doi:10.1002/jpln.201200061, 2014.

Yang, F., Tan, J., Shi, Z. B., Cai, Y., He, K., Ma, Y., Duan, F., Okuda, T., Tanaka, S., and Chen, G.: Five-year record of atmospheric precipitation chemistry in urban Beijing, China, Atmos. Chem. Phys., 12, 2025-2035, doi:10.5194/acp-12-2025-2012, 2012.

Yang, L., Ren, Y., and Jia, L.: Preliminary study of chemical composition of precipitation at Wudaoliang, Qinghai Province, Plateau Meteorol., 10, 209-216, 1991 (in Chinese with English abstract).

Yang, Y. H., Ji, C. J., Ma, W. H., Wang, S. F., Wang, S. P., Han, W. X., Mohammat, A., Robinson, D., and Smith, P.: Significant soil acidification across northern China's grasslands during 1980s2000s, Glob. Change Biol., 18, 2292-2300, doi:10.1111/j.13652486.2012.02694.x, 2012.

Yang, Z., Ou Yang, H., Xu, X., and Yang, W.: Spatial heterogeneity of soil moisture and vegetation coverage of alpine grassland 
in permafrost area of the Qinghai-Tibet Plateau, J. Nat. Resour., 25, 426-434, doi:10.11849/zrzyxb.2010.03.008, 2010 (in Chinese with English abstract).

Yao, T., Thompson, L. G., Mosbrugger, V., Zhang, F., Ma, Y., Luo, T., Xu, B., Yang, X., Joswiak, D. R., Wang, W., Joswiak, M. E., Devkota, L. P., Tayal, S., Jilani, R., and Fayziev, R.: Third Pole Environment (TPE), 3, 52-64, doi:10.1016/j.envdev.2012.04.002, 2012.

Yao, T. D., Masson-Delmotte, V., Gao, J., Yu, W. S., Yang, X. X., Risi, C., Sturm, C., Werner, M., Zhao, H. B., He, Y., Ren, W., Tian, L. D., Shi, C. M., and Hou, S. G.: A review of climatic controls on $\delta^{18} \mathrm{O}$ in precipitation over the Tibetan Plateau: observations and simulations, Rev. Geophys., 51, 525548, doi:10.1002/rog.20023, 2013.

Zaehle, S.: Terrestrial nitrogen - carbon cycle interactions at the global scale, Philos. T. R. Soc. B, 368, L01401, doi:10.1098/rstb.2013.0125, 2013.

Zaehle, S. and Friend, A. D.: Carbon and nitrogen cycle dynamics in the O-CN land surface model: 1. Model description, sitescale evaluation, and sensitivity to parameter estimates, Global Biogeochem. Cycles, 24, GB1005, doi:10.1029/2009gb003521, 2010.

Zaehle, S., Friedlingstein, P., and Friend, A. D.: Terrestrial nitrogen feedbacks may accelerate future climate change, Geophys. Res. Lett., 37, 20130125, doi:10.1029/2009g1041345, 2010.

Zbieranowski, A. L. and Aherne, J.: Long-term trends in atmospheric reactive nitrogen across Canada: 1988-2007, Atmos. Environ., 45, 5853-5862, doi:10.1016/j.atmosenv.2011.06.080, 2011.

Zhang, D. D., Peart, M., Jim, C. Y., He, Y. Q., Li, B. S., and Chen, J. A.: Precipitation chemistry of Lhasa and other remote towns, Tibet, Atmos. Environ., 37, 231-240, doi:10.1016/S13522310(02)00835-X, 2003.

Zhang, M., Wang, S., Wu, F., Yuan, X., and Zhang, Y.: Chemical compositions of wet precipitation and anthropogenic influences at a developing urban site in southeastern China, Atmos. Res., 84, 311-322, doi:10.1016/j.atmosres.2006.09.003, 2007.
Zhang, N. N., He, Y. Q., Cao, J. J., Ho, K. F., and Shen, Z. X.: Long-term trends in chemical composition of precipitation at Lijiang, southeast Tibetan Plateau, southwestern China, Atmos. Res., 106, 50-60, doi:10.1016/j.atmosres.2011.11.006, 2012.

Zhang, X. Y., Arimoto, R., Cao, J. J., An, Z. S., and Wang, D.: Atmospheric dust aerosol over the Tibetan Plateau, J. Geophys. Res.-Atmos., 106, 18471-18476, doi:10.1029/2000jd900672, 2001.

Zhang, X. Y., Jiang, H., Zhang, Q. X., and Zhang, X.: Chemical characteristics of rainwater in northeast China, a case study of Dalian, Atmos. Res., 116, 151-159, doi:10.1016/j.atmosres.2012.03.014, 2012.

Zhang, Y. J., Kang, S. C., You, Q. L., and Xu, Y. W.: Climate in the Nam Co basin, in: Modern environmental processes and changes in the Nam Co basin, Tibetan Plateau, edited by: Kang, S. C., Yang, Y. P., Zhu, L. P., and Ma, Y. M., China Meteorological Press, Beijing, 15-24, 2011 (in Chinese).

Zhang, Y. L., Li, B. Y., and Zheng, D.: A discussion on the boundary and area of the Tibetan Plateau in China, Geographical Res., 21, 1-8, 2002 (in Chinese with English abstract).

Zhao, H. B., Xu, B. Q., Yao, T. D., Tian, L. D., and Li, Z.: Records of sulfate and nitrate in an ice core from Mount Muztagata, central Asia, J. Geophys. Res.-Atmos., 116, D13304, doi:10.1029/2011jd015735, 2011.

Zhao, Z. Z., Cao, J. J., Shen, Z. X., Xu, B. Q., Zhu, C. S., Chen, L. W. A., Su, X. L., Liu, S. X., Han, Y. M., Wang, G. H., and Ho, K. F.: Aerosol particles at a high-altitude site on the Southeast Tibetan Plateau, China: Implications for pollution transport from South Asia, J. Geophys. Res-Atmos., 118, 11360-11375, doi:10.1002/jgrd.50599, 2013.

Zheng, W., Yao, T. D., Joswiak, D. R., Xu, B. Q., Wang, N. L., and Zhao, H. B.: Major ions composition records from a shallow ice core on Mt. Tanggula in the central Qinghai-Tibetan Plateau, Atmos. Res., 97, 70-79, doi:10.1016/j.atmosres.2010.03.008, 2010. 